\title{
RENAL FUNCTION IN BURNED PATIENTS AND ITS RELATIONSHIP TO MORPHOLOGICAL CHANGES
}

BY

\author{
I. G. GRABER AND S. SEVITT \\ From the Birmingham Accident Hospital and M.R.C. Burns and Industrial Injuries Research Unit
}

(RECEIVED FOR PUBLICATION JUNE 26, 1958)

Renal dysfunction not infrequently follows severe burns, but much of its nature and pathogenesis is as obscure as its relationship to mortality. Previous studies showed that the b'ood urea rose considerably both in subjects who became severely oliguric, and in others with a normal urine flow, whilst the kidneys of both groups of patients often portrayed the same histological picture of diffuse distal tubular necrosis (Sevitt, 1956a). The high plasma:urine (P:U) ratios of sodium and chloride found indicated renal-tubular ability to absorb these ions in spite of the tubular necrosis and azotaemia. These findings did not support the thesis that acute renal failure is always characterized by anuria or severe oliguria and that degeneration or necrosis of the renal tubules is its morphological expression or pathological basis.

The present investigation of renal function was planned to take into account the rapid changes in blood volume, haemodynamics, and fluid exchange which occur in extensively burned treated subjects and to time the onset of changes in renal function. Renal function is influenced by the early onset of oligaemia, mainly from the exudation of a plasma-like fluid into the burned area, by the administration of fluid which combats the oligaemia, by haemoglobinuria from red cell destruction, and by cardiovascular and hormonal changes. During the first two or three days fluid continues to be lost into the burn oedema ; then the oedema is reabsorbed and an additional load is placed on the kidneys. Serial hourly specimens of urine with appropriate blood samples were therefore examined to establish the patterns of glomerular and tubular function, and these were related to the histological changes in the kidneys of those who subsequently died.

The results indicate that an important defect in acute renal failure is glomerular even though tubular necrosis and blockage by casts is often present. A sufficient fall in the glomerular filtration rate (G.F.R.) precipitates azotaemia, but the presence or absence of oliguria is determined both by the degree of reduction in filtration and by the tubular reabsorption of water. A decrease in the latter may adequately counterbalance the reduced G.F.R. and the urine flow may then be normal or even polyuric. Oliguria results when the decreased reabsorption does not balance the severe reduction in filtration. Continued tubular activity is indicated by the low urinary concentration of sodium and chloride, by the wave of increased potassium excretion after burning, and by the renal ability to discriminate in the handling of water, creatinine, urea, sodium, potassium, and chloride. Similar patterns of electrolyte excretion were found in non-azotaemic, temporarily azotaemic, and persistently azotaemic subjects with or without oliguria and with or without tubular necrosis. The relationship between severe azotaemia and tubular necrosis is inconstant and the major functional defect is glomerular and not tubular in origin.

\section{PATIENTS AND METHODS Patients}

Table I gives the necessary clinical details of the patients studied.

Seventeen patients (14 women) were studied, eight of whom were 12 years of age or younger, six between 36 and 54 years of age, and the remainder older than 65 years. In four patients the extent of burning was $18 \%$ to $30 \%$ of the body area, $30 \%$ to $40 \%$ in another four, and $40 \%$ to $90 \%$ in the remaining nine. Eleven patients died three to 18 days after burning. Four of the six survivors had burns between $20 \%$ and $30 \%$ of the body area.

Thirteen patients (Cases 4 to 7 and 9 to 17) were extensively burned $(25 \%$ to $90 \%)$ "shock cases" admitted consecutively. Cases 1 to 3 were added as examples of less extensively burned subjects $(18 \%$ to $20 \%$ ). Case 8 was admitted from another hospital two days after burning; the others were admitted between one and three and a half hours after the accident. 
TABLE I

THE PATIENTS

\begin{tabular}{|c|c|c|c|c|c|c|c|}
\hline \multirow[b]{2}{*}{$\begin{array}{l}\text { Case } \\
\text { No. }\end{array}$} & \multirow{2}{*}{\multicolumn{2}{|c|}{$\begin{array}{l}\text { Sex } \\
\text { and } \\
\text { Age } \\
\text { (Yr.) }\end{array}$}} & \multirow[b]{2}{*}{$\begin{array}{c}\text { Percentage } \\
\text { Body } \\
\text { Area } \\
\text { Burned }\end{array}$} & \multicolumn{2}{|c|}{ Intravenous Therapy } & \multirow[b]{2}{*}{$\begin{array}{c}\text { Lived or Died } \\
\text { (Survival } \\
\text { Period in } \\
\text { Days) }\end{array}$} & \multirow[b]{2}{*}{ Clinical and Necropsy Notes } \\
\hline & & & & $\begin{array}{l}\text { Period from } \\
\text { Burn to } \\
\text { Onset of } \\
\text { Therapy (hr.) }\end{array}$ & $\begin{array}{c}\text { Litres of } \\
\text { Plasma and } \\
\text { Blood in } \\
\text { First } 48 \text { Hours }\end{array}$ & & \\
\hline 1 & $\mathbf{F}$ & 74 & 18 & 2 & $3 \cdot 7$ & D, (3) & Died rather suddenly. Atelectasis lower lobe left \\
\hline $\begin{array}{l}2 \\
3 \\
4 \\
5\end{array}$ & $\begin{array}{l}\mathbf{F} \\
\mathbf{F} \\
\mathbf{M}\end{array}$ & $\begin{array}{l}10 \\
40 \\
12 \\
53\end{array}$ & $\begin{array}{l}20 \\
20 \\
25 \\
30\end{array}$ & $\begin{array}{l}1 \frac{1}{2} \\
2 \\
1 \\
2\end{array}$ & $\begin{array}{r}5 \cdot 4 \\
8 \cdot 2 \\
8 \cdot 2 \\
14 \cdot 3\end{array}$ & $\begin{array}{c}\mathrm{L} \\
\mathrm{L} \\
\mathrm{L} \\
\mathrm{D},(5)\end{array}$ & $\begin{array}{l}\text { Primary excision and grafting } \\
\text { Primary excision and grafting } \\
\text { Primary excision and grafting. Considerable post- }\end{array}$ \\
\hline $\begin{array}{l}6 \\
7 \\
8\end{array}$ & $\begin{array}{l}\mathbf{F} \\
\mathbf{F}\end{array}$ & $\begin{array}{c}3 \frac{1}{2} \\
9\end{array}$ & $\begin{array}{l}30 \\
35 \\
36\end{array}$ & $\begin{array}{l}1 \\
2 \\
*\end{array}$ & $\begin{array}{l}1 \cdot 2 \\
4 \cdot 8 \\
3 \cdot 4\end{array}$ & $\begin{array}{l}\mathrm{L} \\
\mathrm{D},(8) \\
\mathrm{D},(18)\end{array}$ & operative bleeding into dressing. Nephrosclerosis \\
\hline $\begin{array}{r}9 \\
10\end{array}$ & $\mathbf{F}$ & $\begin{array}{l}12 \\
66\end{array}$ & $\begin{array}{l}40 \\
40\end{array}$ & $\begin{array}{l}3 \frac{1}{2} \\
1 \frac{1}{2}\end{array}$ & $\begin{array}{r}11 \cdot 1 \\
4 \cdot 8\end{array}$ & $\mathrm{~L},(6)$ & $\begin{array}{l}\text { Small acuto duodenal ulcer. Slight fatty liver } \\
\text { Flabby, fatty heart. Acute duodenal uicer. ? Sep- }\end{array}$ \\
\hline $\begin{array}{l}11 \\
12 \\
13 \\
14 \\
15 \\
16 \\
17\end{array}$ & $\begin{array}{l}\mathbf{F} \\
\mathbf{F} \\
\mathbf{F} \\
\mathbf{F} \\
\mathbf{F} \\
\mathbf{M} \\
\mathbf{M}\end{array}$ & $\begin{array}{r}45 \\
5 \\
54 \\
36 \\
2 \\
45 \\
5\end{array}$ & $\begin{array}{l}45 \\
50 \\
50 \\
60 \\
65 \\
85 \\
90\end{array}$ & $\begin{array}{l}3 \\
1 \\
2 \\
2 \frac{1}{2} \\
2 \frac{1}{2} \\
3 \\
1\end{array}$ & $\begin{array}{r}11 \cdot 0 \\
5 \cdot 4 \\
5.9 \\
14 \cdot 2 \\
4 \cdot 8 \\
11 \cdot 3 \\
5.9\end{array}$ & $\begin{array}{l}\mathrm{D},(12) \\
\mathbf{L} \\
\mathrm{D},(9) \\
\mathrm{D},(5) \\
\mathrm{D},(11) \\
\mathrm{D},(\mathbf{4}) \\
\mathrm{D},(5)\end{array}$ & $\begin{array}{l}\text { Hyperpyrexial attacks } \\
\text { Primary excision and grafting } \\
\text { Bronchopneumonia. Focal nephrosclerosis } \\
\text { Bronchopneumonia. Moderately fatty liver } \\
\text { Lobar atelectasis. Moderately fatty liver } \\
\text { Died rather suddenly. Inhalation of vomit } \\
\text { Burn of larynx, some respiratory obstruction. } \\
\text { Necropsy = acute pulmonary emphysema, cerebral } \\
\text { swelling, multiple tiny haemorrhagic erosions in } \\
\text { gastric mucosa, haemorrhagic ileum }\end{array}$ \\
\hline
\end{tabular}

* Patient treated in another hospital during first two days.

Continuous intravenous therapy for about 48 hours consisting of reconstituted dried citrated plasma supplemented by stored blood and oral fluids was directed against oligaemia and haemoconcentration; it was controlled by repeated haematocrit determinations, by observations on the urine flow, and by close clinical examination. During the first two or three days daily estimations of the red cell volume by the $\mathrm{P}^{32}$ and $\mathrm{Cr}^{51}$ techniques were made by Dr. E. Topley and her colleagues (see Topley and Jackson, 1957) and guided the transfusion of blood.

In Cases 2, 4, 5, and 12 primary excision and grafting of much of the burn was performed seven to 18 hours after burning. The considerable operative and post-operative blood loss was replaced, guided by swab weighing and red cell volume determinations, but one patient (Case 5) went through a post-operative oligaemia lasting several hours before it was corrected by transfusion.

The burns of the other patients were dusted with lactose-penicillin powder and covered with sterile towels during the shock period. Grafting operations were done two to three weeks after burning.

After the shock period a high-protein, high-calorie diet was given by intragastric drip until a normal diet was judged appropriate. The diet was altered to a high-calorie, low-protein kind in those with severe oliguria.

\section{Methods}

Frequent blood sampling, accurate haematocrit estimation, and red cell volume studies were facilitated in nine patients (Cases 6, 7, 9, 10, 11, 12, 14, 15, and
17) by guiding a polythene catheter into a large central vein under local anaesthesia soon after admission. Otherwise blood was obtained by venous punctures.

Plasma creatinine was repeatedly determined in $\mathbf{1 2}$ patients (Cases 4, 6, 7, 9 to 17) three to seven times in the first 24 hours after burning, two to four times in the second 24 hours, one to four times in the third period, and then daily; occasional estimates were made in others. In two patients (Cases 13 and 16) insufficient blood necessitated the pooling of several hourly specimens and the creatinine values were plotted at the midpoint of the period. Plasma or blood urea was repeatedly estimated in 15 patients ; in 10 (Cases $4,5,7,9$ to 12,14 to 16) it was determined two to four times in the first 24 hours, one to four times in the second and third 24 hours, and then daily. Plasma sodium and potassium were estimated as often or more frequently in the first 24 hours, but plasma chloride and bicarbonate were determined daily or less often. The serial plasma creatinine, urea, and sodium values were plotted against time on semilog paper and values were extrapolated for clearance and other calculations.

An indwelling catheter was passed on admission and the bladder was emptied. Urine was collected hourly during the first 48 hours and then at fourhourly or longer intervals, but in six patients (Cases 4 and 12 to 16) hourly collections were continued for 60 to 100 hours. In 13 patients serial estimations of the creatinine, sodium, and potassium were made. Repeated urea analyses were made in seven patients (Cases 6, 7, 9, 10, 12, 14, and 15) and there were daily estimates in six others. Serial urea, inulin, and 
TABLE II

SUMMARY OF FINDINGS

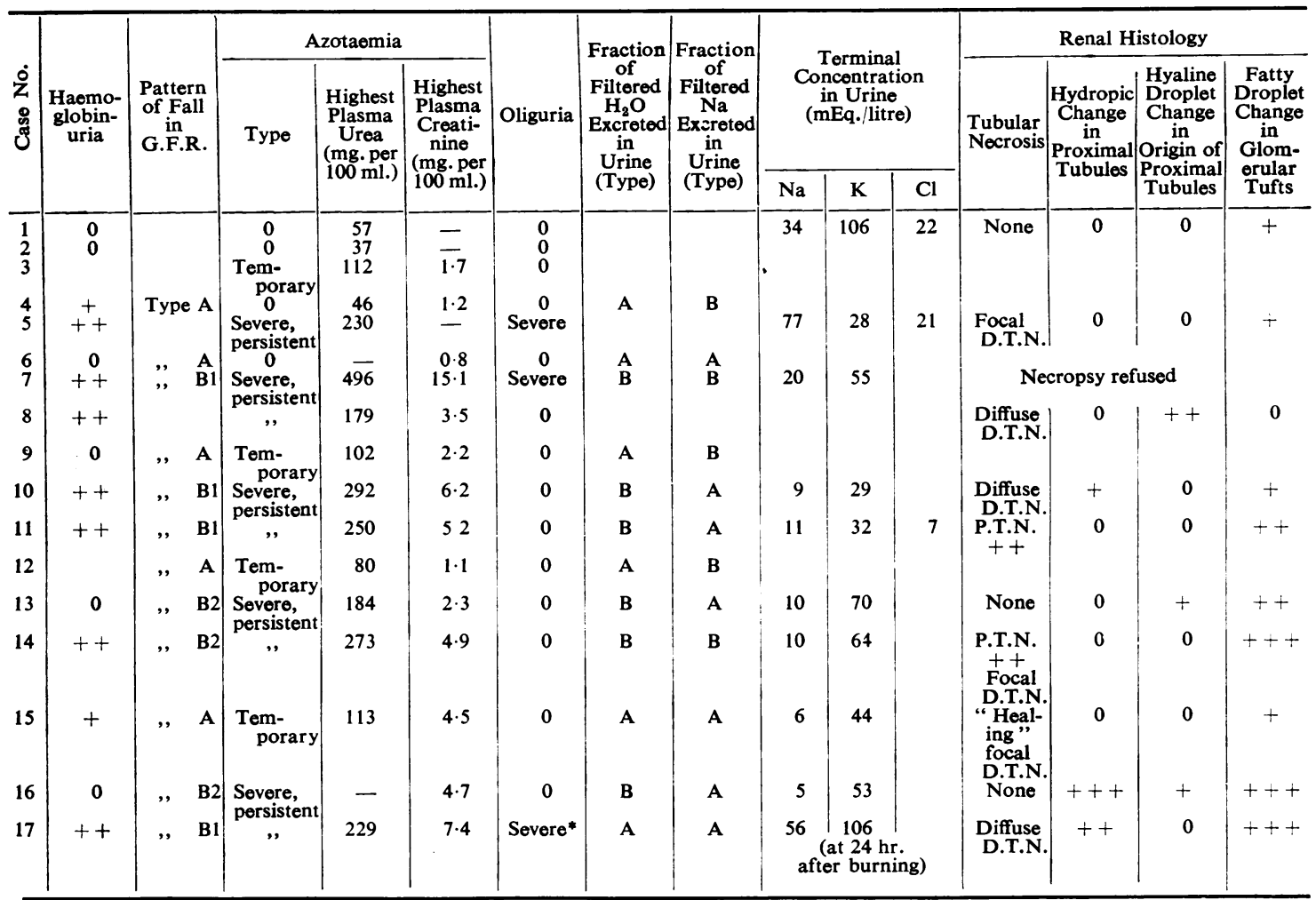

Pattern of fall in G.F.R.: Type A=temporary fall with return to normal; Type B1=early severe and persistent fall; Type B2=early moderate fall with subsequent decline. Fraction of filtered $\mathrm{H}_{2} \mathrm{O}$ excreted: $\mathrm{A}=$ early increase with return to normal; $\mathrm{B}=$ persistent and/or progressive increase. Fraction of filtered $\mathrm{Na}$ excreted: $\mathbf{A}=$ normal or decreased from admission. $\mathrm{B}=\mathrm{early}$ increase with anuria* after 24 hours. D.T.N. $=$ distal tubular necrosis. P.T.N. $=$ proximal tubular necrosis. $0=$ little or no oliguria.

creatinine clearances were calculated from the formula $\frac{\mathrm{UV}}{\mathrm{P}}$. Urinary chloride was determined in 11 patients, hourly in three (Cases 7,12 , and 14), and daily in the others.

Biochemistry.-Creatinine in plasma and urine was estimated by a modification of the method of Brod and Sirota (1948). The colour was read at $510 \mathrm{~m} \mu$ at 60 minutes instead of 15 minutes after adding the alkaline picrate reagent.

Simultaneous inulin and creatinine clearances were carried out in Cases 12 and 14 for 12 and eight urine collection periods respectively during the shock phase, each period lasting one to two hours. For the inulin clearances a steady plasma concentration was attained by varying the concentration of the intravenous infusion.

Inulin was estimated by a modification of the method of Rolf, Surtshin, and White (1949). The water bath was at $70^{\circ} \mathrm{C}$. instead of $75^{\circ} \mathrm{C}$. and $15 \mathrm{~g}$. instead of $18 \mathrm{~g}$. of diphenylalanine per litre of acetic acid- $\mathrm{HCl}$ mixture was used. This raises the fructose! glucose differentiation from 1 in 50 to 1 in 92 (Graber and Hancock, 1955). The colour which developed was read at $520 \mathrm{~m} \mu$. All colorimetric readings were made on a "unicam" 600 spectrophotometer.

Plasma and urinary sodium and potassium were estimated by flame photometry (E.E.L.) ; plasma and urinary chloride by a modification of the method of Schales and Schales (1941) diluting with a nitric acid/ sodium citrate buffer at $p \mathrm{H} 1.5$ instead of water; and plasma or blood urea by a urease-Nesslerization colorimetric method. Urinary urea was determined by the alkaline-hypobromite technique. Lactose in urine was detected by the methylamine test (Fearon, 1946).

Histology.-Kidneys from 10 fatally burned patients were studied. The bodies were refrigerated soon after death. The interval before necropsy was less than eight hours in five cases $(1,8,10,15$, and 17), in three others (Cases 5,13 , and 16) between 10 and 20 hours, and only in two cases was it greater than 24 hours (Case 11-27 hours; Case 14-48 hours). Blocks from both kidneys ( 2.5 to $3.5 \mathrm{~cm}$. long) were fixed in neutral formol-saline (in Cases 5 and 14 additional blocks were also fixed in formol-alcohol). 
Paraffin sections were stained by haematoxylin and eosin, picromallory, periodic-acid-Schiff, Gram, prussian blue, Pickworth's benzidine, and other methods. Frozen sections were stained for lipids by oil red $\mathrm{O}$ and counterstained by light green or aniline blue, the latter for outlining the glomerular basement membrane in relationship to glomerular lipid.

\section{RESULTS}

The results are set out in Table II.

\section{Validity of Creatinine Clearance as a Measure of Glomerular Filtration Rate}

We believe that variations in the published ratios of creatinine clearance to inulin clearance (Ccr: $\mathrm{Cin}$ ) are mainly variations in the method of estimating plasma creatinine and are not differences in the tubular handling of creatinine. The present method for estimating plasma creatinine was used in more than 500 simultaneous creatinine and inulin clearances in a variety of cases and give a mean Ccr : Cin ratio of 0.87 (Graber, 1955). A similar mean value was obtained for the 20 clearance ratios made during the shock phase in two of the present cases (Table III).

TABLE III

SIMULTANEOUS INULIN AND CREATININE CLEARANCE VALUES (ML. PER MINUTE) IN TWO PATIENTS

\begin{tabular}{|c|c|c|c|c|}
\hline \multirow{2}{*}{$\begin{array}{c}\text { Hours } \\
\text { after } \\
\text { Burning }\end{array}$} & \multicolumn{2}{|c|}{ Case 12} & \multicolumn{2}{|c|}{ Case 14} \\
\hline & $\begin{array}{l}\text { Inulin } \\
\text { Clearance } \\
\text { (ml./min.) }\end{array}$ & $\begin{array}{l}\text { Creatinine } \\
\text { Clearance } \\
\text { (ml./min.) }\end{array}$ & $\begin{array}{l}\text { Inulin } \\
\text { Clearance } \\
\text { (ml./min.) }\end{array}$ & $\begin{array}{c}\text { Creatinine } \\
\text { Clearance } \\
\text { ml./min.) }\end{array}$ \\
\hline $\begin{array}{l}27 \\
28 \\
29 \\
30 \\
31 \\
32 \\
33 \\
34 \\
35 \\
36 \\
46 \\
47 \\
48\end{array}$ & $\begin{array}{l}43 \\
53 \\
37 \\
32 \\
38 \\
48 \\
18 \\
18 \\
25 \\
28 \\
16 \\
22\end{array}$ & $\begin{array}{l}41 \\
43 \\
26 \\
24 \\
33 \\
41 \\
18 \\
18 \\
28 \\
26 \\
17 \\
22\end{array}$ & $\begin{array}{l}42 \\
40 \\
42 \\
39 \\
27 \\
52 \\
24 \\
41 \\
= \\
=\end{array}$ & $\begin{array}{l}40 \\
40 \\
38 \\
31 \\
20 \\
42 \\
19 \\
45 \\
= \\
=\end{array}$ \\
\hline $\begin{array}{l}\text { Mean } \\
\text { Ccr: Cin }\end{array}$ & \multicolumn{2}{|c|}{0.90} & \multicolumn{2}{|c|}{0.89} \\
\hline
\end{tabular}

Case 12 (mean normal G.F.R. $35 \mathrm{ml}$. per minute) developed a sligh temporary azotaemia and survived, whilst Case 14 (mean normal G.F.R. 90 ml. per minute) became considerably azotaemic and died G.F.R. $90 \mathrm{ml}$. per minute) became considerably azotaemic and died
with renal tubular necrosis. Note that the simultaneous values for with renal tubular necrosis. Note that the simultaneous values for
inulin and creatinine clearances are very similar in each case, as are the mean ratios of Ccreat: Cin ratios.

It has been suggested that the low clearance $\left(\frac{U V}{P}\right)$ values of creatinine, inulin, urea, and other substances found in patients with tubular necrosis results from an unselective back diffusion into the blood of filtered water and solutes which the tubular damage permits (Phillips and Hamilton, 1948 ; Bull, Joekes, and Lowe, 1950). Azotaemia and the low creatinine clearance then results from back diffusion and not from a low
G.F.R. The possibility of back diffusion cannot be eliminated, but if it occurs the affected nephron behaves like a capillary and not like renal tissue ; the result is a reduction in the functioning nephron mass and not an alteration in function.

We offer three kinds of evidence that nonspecific reabsorption is of little importance in determining urine composition. First, the Ccr: Cin ratio was identical in Cases 12 and 14 (Table III). One had severe azotaemia and tubular necrosis and the other rapidly recovered full renal function. Secondly, Curea:Ccr ratios varied considerably in the same patient ranging from 0.1 to 1.4 (Fig. 1). The ratios were generally low in the early period after burning, tended to $\mathcal{G}$ continue low in severely azotaemic patients, but $ᄋ$ rose in the others. Low and varying ratios indicate tubular discrimination between urea and creatinine and do not support the theory of unselective back diffusion. Thirdly, the low sodium and

\section{RATIO \\ CLEARANCE UREA: CREATININE}

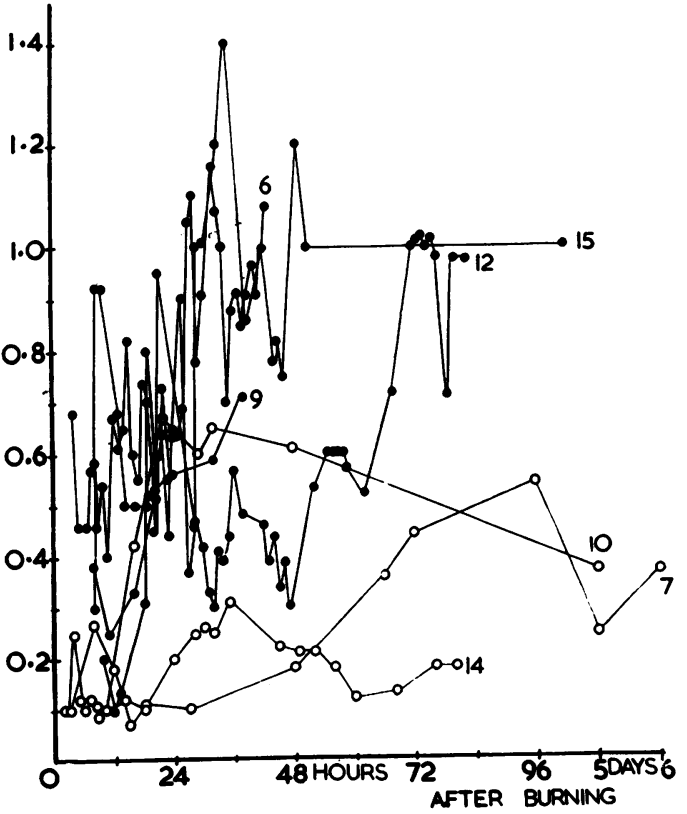

FIG. 1.-Serial ratios of urea clearance : creatinine clearance in $\mathcal{S}$ seven patients at different times after burning. The black circles are the values from patients without azotaemia or with a moderate temporary azotaemia, whilst the open circles are from patients with severe persistent azotaemia. The numerals refor to case numbers. The ratios fluctuate and range widely from 0.1 to 1.4 . Low ratios generally occur during the first 24 hours in all patients, but they tend to persist in those with $\sigma$ severe azotaemia; this indicates differential tubular handling of creatinine and urea and does not support the theory of unselective tubular reabsorption. 


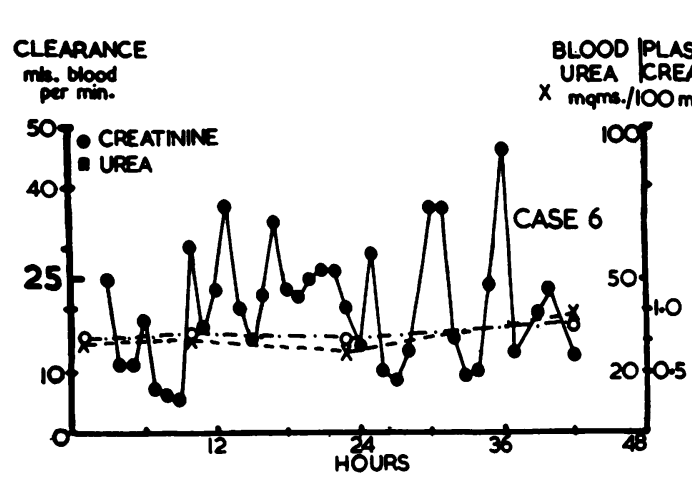

GLONERULAR

GLOMERULAR

mis.

$\times$ UREA KREATH:OO ms.O FILTRATE
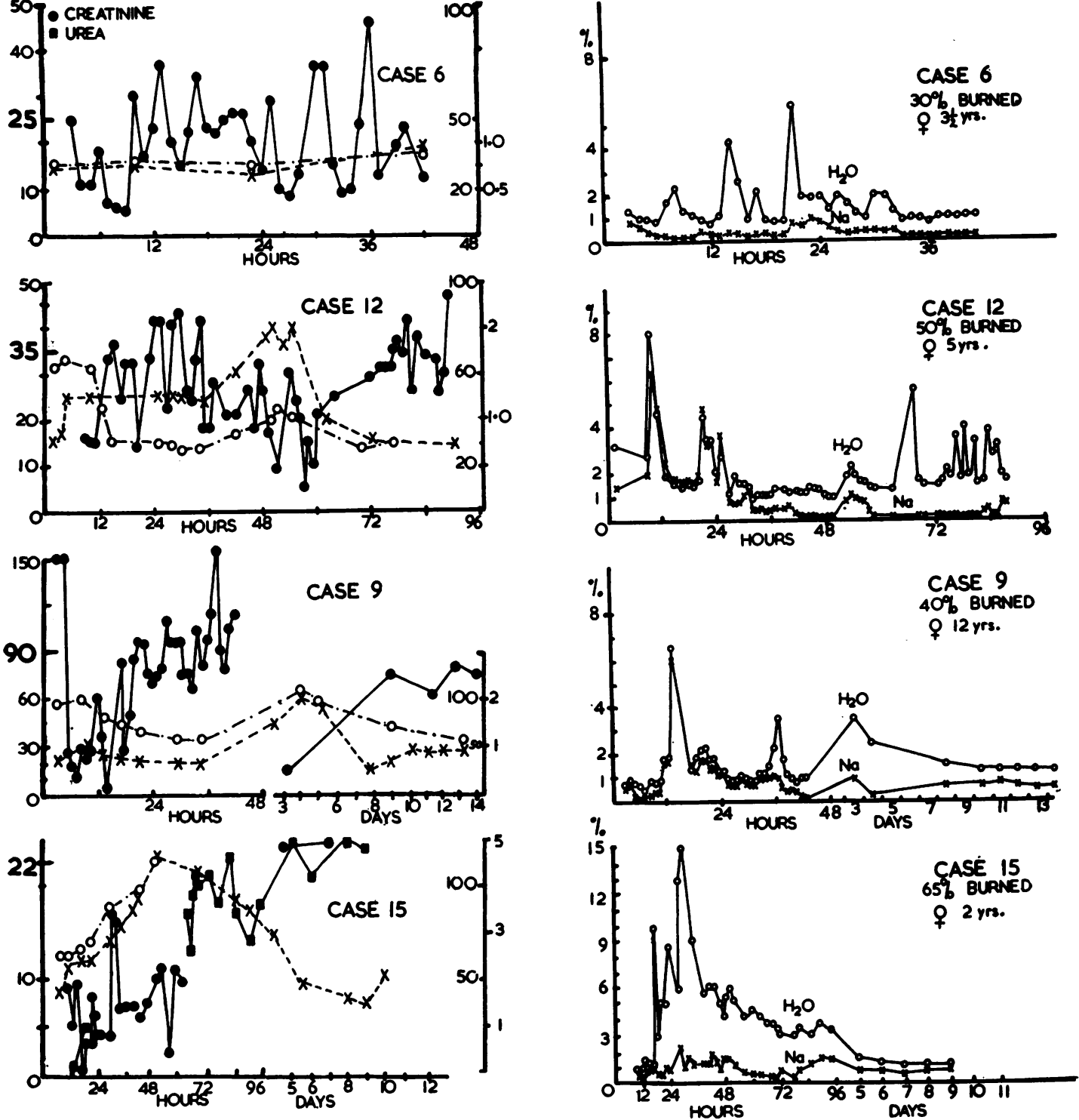

FIG. 2.-The findings in four patients with a reversible fall in’G.F.R. and eithor no azotaemia or a temporary azotaemia (seo text).

Fics. 2, 3, and 4.-The graphs on the left show serial creatinine clearance (G.F.R.), urea clearance, plasma creatinine, and urea values. The expected normal G.F.R. (based on surface area derived from height and age) is shown in heavy type. The graphs on the right show the serial values for the percentage excretion of filtered water and sodium.

chloride concentrations (5 to $11 \mathrm{mEq}$. per litre) and high potassium levels in the urine before death in patients with tubular necrosis (Table II) are incompatible with the theory of unselective reabsorption. Such concentrations which are due to tubular activity could only occur if damaged nephrons were excluded from the urine flow.

\section{Glomerular Filtration and Azotaemia}

Within a few hours of beginning therapy the G.F.R. was found to be falling from a relatively normal or raised value (Cases 6, 7, 9, 10, 13, and 16) or was grossly reduced (Cases 11, 12, 14, 15, and 17, and Figs. 2, 3, and 4). During the first day or two some cases showed considerable 

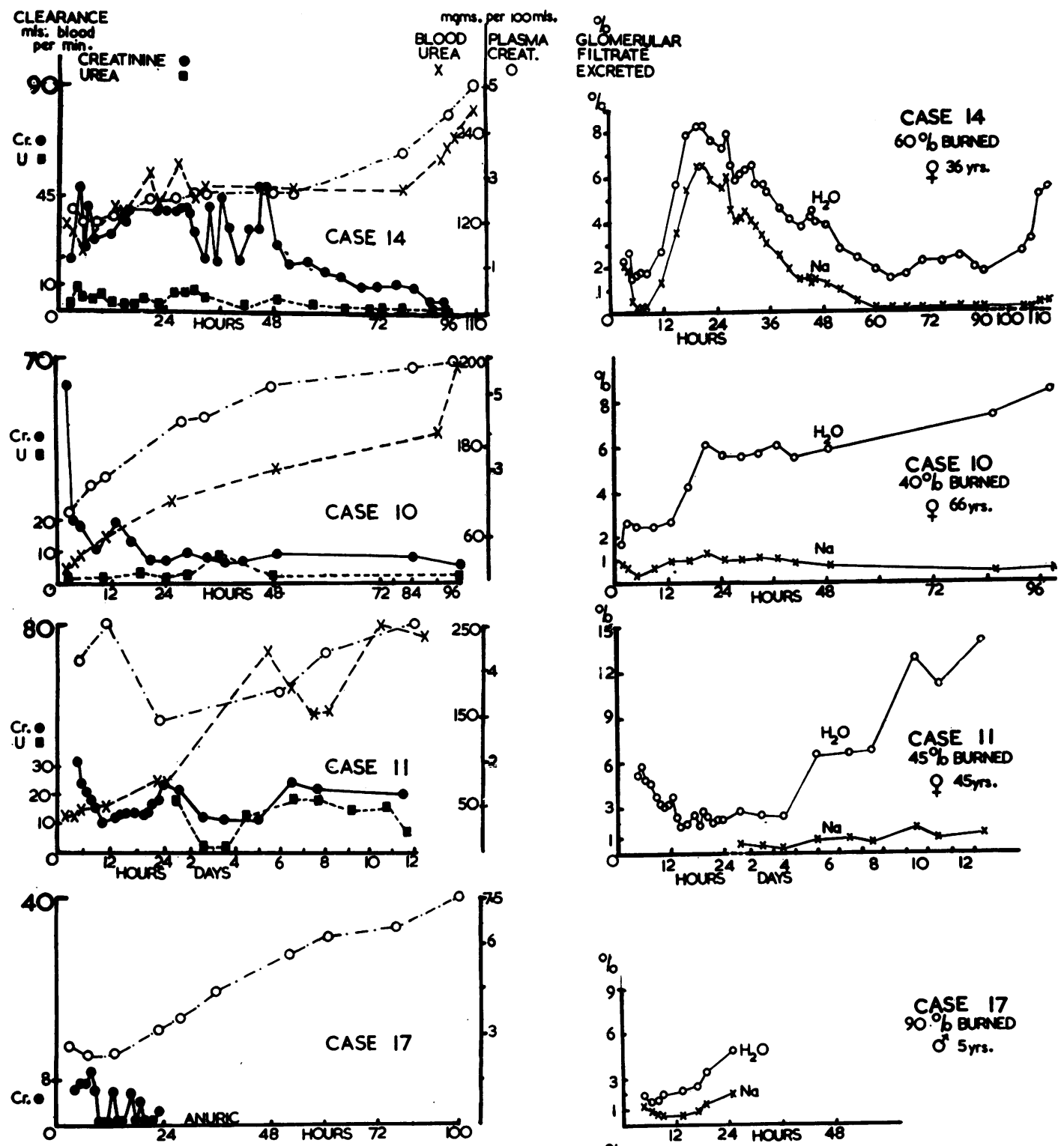

CASE 17

$90 \%$ BUPNED

of 5 rrs.
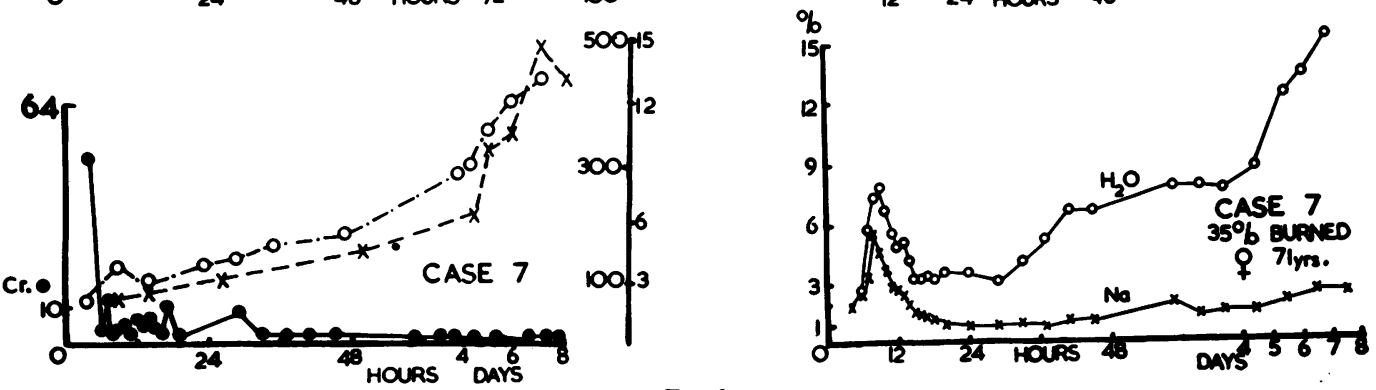

Fig. 3

FIGS. 3 and 4.-The findings in six patients with a persistent fall in the G.F.R. and a severe azotaemia (see text). 
fluctuations in the G.F.R., often from hour to hour. Urine collection faults were excluded when the consecutive specimens of urine differed in creatinine, sodium, and potassium concentration as well as in volume. When similar concentrations were found, variations in creatinine clearance were considered to be collection faults and the results were averaged for the period. The rapidity of change points to the danger of drawing conclusions from only one or two spot estimates in any one case. Random and unrelated fluctuations in volume and specific gravity were also recorded by Didenko (1956) in consecutive three-hourly specimens of urine from extensively burned patients during the shock phase. Azotaemia developed when the fluctuations in the G.F.R. were below a mean value of about $50 \%$ of normal for 24 hours, but with higher mean values the periods of fall appeared to be too short to produce a significant effect, e.g., Case 6 (Fig. 2). The results may be divided into two main groups. Type A (Fig. 2) consists of patients with a considerable but temporary reduction in the mean G.F.R. either without azotaemia or coinciding with a phase of moderate azotaemia. Type B (Figs. 3 and 4) consists of patients with a persistently low G.F.R. and severe azotaemia, and may be divided into two subgroups, namely, B1, those in whom the G.F.R. fell to a low value soon after burning and remained low until death and in whom the azotaemia progressively increased; B2, those in whom the early fall in the G.F.R. was less considerable but in whom there was a further decrease and in whom the azotaemia developed in a variable fashion. One case had features of both subgroups.

A. Temporary Fall in G.F.R. with or without Reversible Azotaemia.-Eight patients (Cases 1 to $4,6,9,12$, and 15 ) fall into this category. Six were children between 2 and 12 years, and in the two adults the burns covered $20 \%$ of the body area or less. Serial creatinine clearances (Cases $4,6,9,12$, and 15) (Fig. 2) showed an irregular fall in the G.F.R. (lowest values $5 \%$ to $40 \%$ of normal), then an irregular return to normal-within 24 hours of burning in four patients and by 72 hours in Case 15. Cases 9 and 12 had a subsequent fall in the G.F.R. and an additional peak of azotaemia. The mean values ranged from $30 \%$ to $50 \%$ of normal during the first 12 hours in the different patients, from $18 \%$ to $90 \%$ during the second 12 hours, and from $45 \%$ to $110 \%$ of normal during the second 24 hours.

Four patients were without significant azotaemia (Cases 1, 2, 4, and 6), but in Cases 3, 9, 12, and 15 the blood urea and plasma creatinine levels rose for a few days, reaching maxima of 112,102 , 80 , and $113 \mathrm{mg}$. \% urea and $1.7,2.2,1.1$, and 4.5 mg. \% creatinine respectively (Table II) and then returned to normal. Six survived; Cases 1 and 15 died of causes unrelated to renal failure.

The urine output gave no cause for anxiety, the patients passing a relatively normal volume for their age.

B. Persistent Fall in G.F.R. and Severe Azotaemia.-Nine patients (seven adults) fall into this category (Cases 5, 7, 8, 10,11, 13, 14, 16, and 17), all of whom died between four and 19 days after burning. The severe persistent azotaemia suggests that renal failure contributed to their deaths.

Cases 7, 10, 11, and 17 (Fig. 3) formed the subgroup B1 in whom the G.F.R. fell to between $8 \%$ and $17 \%$ of normal within a few hours of burning, and remained at very low levels until death supervened. The mean values during the first 12 hours varied from $10 \%$ to $25 \%$ of normal, during the second 12 hours from $10 \%$ to $15 \%$, and during the second 24 hours from $7 \%$ to $25 \%$.
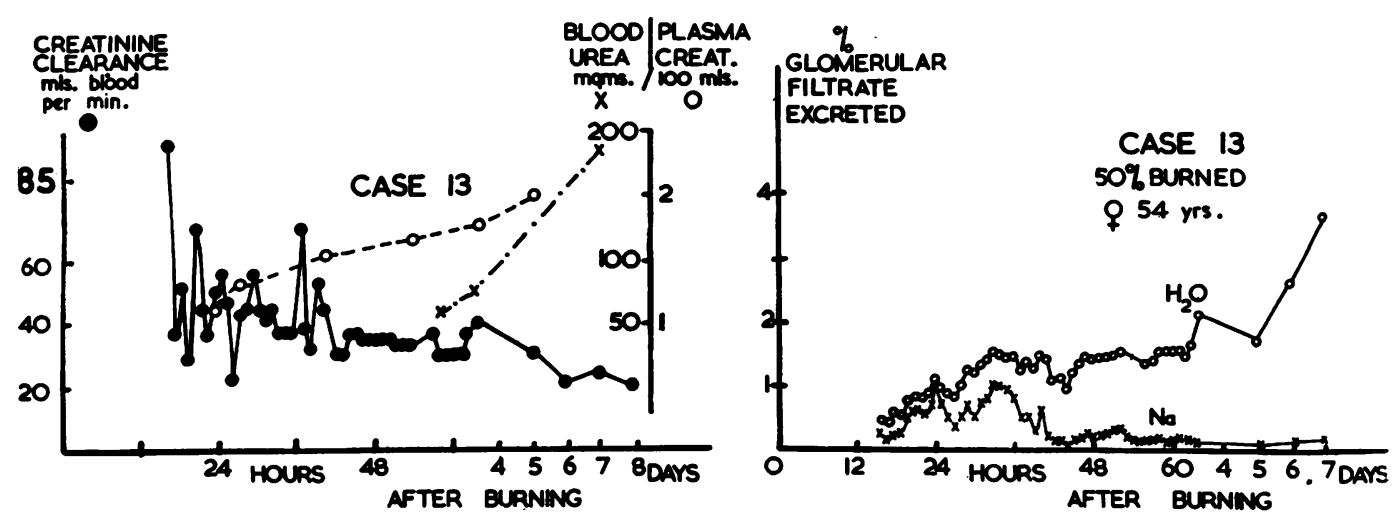

FIG. 4 
Cases 13 (Fig. 4), 14 (Fig. 3), and 16 formed the subgroup B2 in whom the mean G.F.R. was $35 \%$ to $60 \%$ of normal during the first 24 hours and then declined to between $6 \%$ and $25 \%$ during the next few days. For example, in Case 14 the G.F.R. fell rapidly and fluctuated around a mean value of $40 \%$ of normal for the first 48 hours, then fell to $11 \%$ at 72 hours, and to $6 \%$ at 96 hours.

In Case 8 the G.F.R. on days three to five was about $10 \%$ of normal. Creatinine clearance studies were not made in Case 5 , but urea clearances were only 0.1 to $0.2 \mathrm{ml}$. per minute.

The rise in the plasma creatinine and urea was considerable and generally progressive, but a temporary plateau or fall in azotaemia was found in a few patients. The maximum plasma urea levels ranged from 179 to $496 \mathrm{mg}$. per $100 \mathrm{ml}$. and the maximum creatinine values from 2.3 to $15.1 \mathrm{mg}$. per $100 \mathrm{ml}$. (Table II).

Cases 5, 7, and 17 had severe oliguria which developed within a few hours of burning, and the remainder had little or no reduction in urine flow. Case 7 passed only 279, 90, 116, 130, 210, 278, and $285 \mathrm{ml}$. of urine on successive days ; Case 5 only 50 to $100 \mathrm{ml}$. per day, and Case 17 passed $70 \mathrm{ml}$. of urine in the first 24 hours and almost none after this.

In the others the urine flow was not greatly reduced except for short periods early in resuscitation and terminally, and was sometimes polyuric. For example, Case 10 passed $185 \mathrm{ml}$. during the first eight hours of resuscitation and successive 24-hour total volumes were $558,>700,>826,812$, and $730 \mathrm{ml}$. of urine. Nevertheless the plasma urea and creatinine mounted steadily from $32 \mathrm{mg}$. and $1.9 \mathrm{mg}$. respectively at two hours after burning to $292 \mathrm{mg}$. and $6.2 \mathrm{mg}$. per $100 \mathrm{ml}$. on the fourth day. Case 14 was somewhat different (Figs. 3 and 5). A period of urine flow averaging $33 \mathrm{ml}$. per hour from four to 11 hours after burning was followed by a polyuric output averaging $117 \mathrm{ml}$. per hour for the next 37 hours. The urine flow then decreased and this was associated with a sudden reappearance of numerous brown granular casts, and a further fall in the G.F.R., and a more rapid rise in azotaemia. The change suggested that a new "incident" had affected the kidneys.

\section{Tubular Function}

Our estimate of tubular function is based on the renal ability to reabsorb water, sodium. and

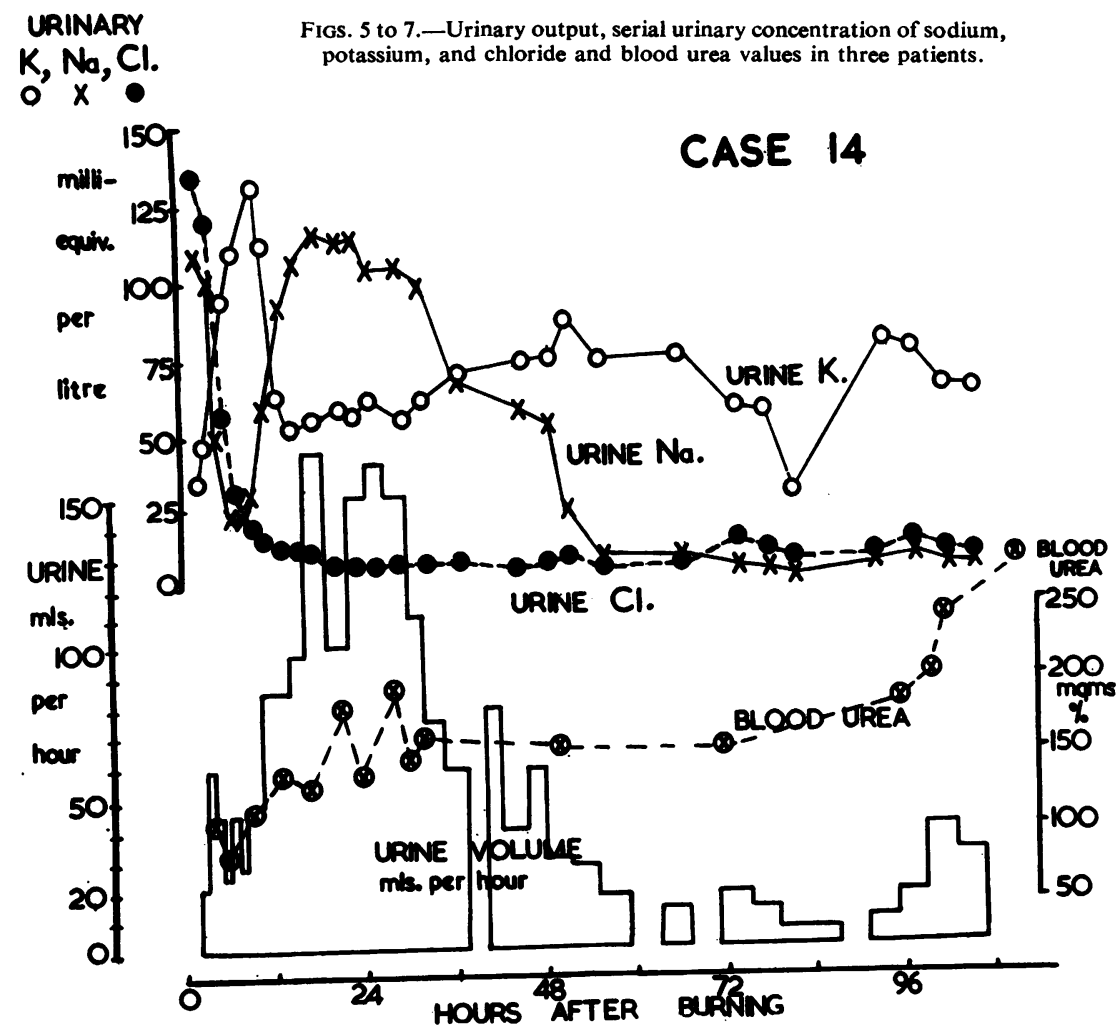

Fig. 5.-Case 14. Note the early onset of a low urinary concentration of chloride, the phases of low sodium excrstion, the high urinary level of potassium, and the absence of oliguria in this patient who developed a severe, persistent azotaemia and extensive necrosis of the proximal renal tubules (cf. Case 12, Fig. 7). 


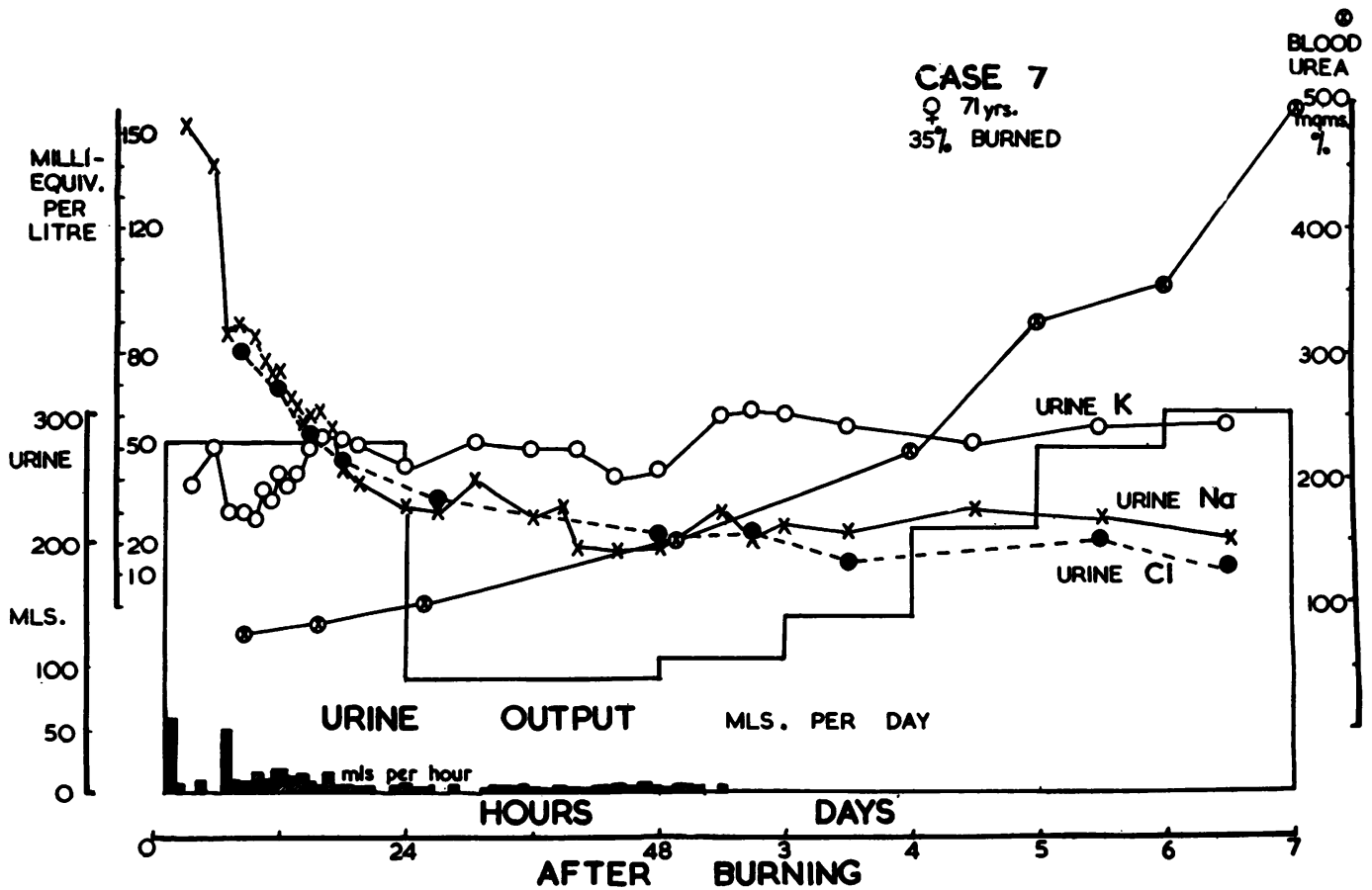

FIG. 6.-Case 7. In this severely oliguric progressively azotaemic patient there is a parallel development of low urinary concentrations of sodium and chloride and a moderately high level of potassium.

chloride, to excrete potassium, and to differentiate between these substances. The differential tubular handling of creatinine and urea has already been referred to.

Excretion of Electrolytes.-The general pattern of sodium excretion (Fig. 5) was a low urinary concentration sometimes preceded by a temporary high concentration. The chloride level rapidly fell to low values whilst the potassium level rapidly increased.

With the possible exception of one severely oliguric patient (Case 5) similar patterns of excretion of sodium, potassium, and chloride occurred in those with little or no azotaemia and in those with severe azotaemia.

Sodium and Potassium.-Three variations in sodium excretion could be distinguished.

(1) The urinary sodium concentration fell sharply after burning, low values were reached within 12 to $\mathbf{4 8}$ hours and were continued for days (Case 7, Fig. 6, Cases 10, 11, 15, 16, and probably Cases 1-3). For example, in Cases 15 and 16 urinary levels of only 10 to $15 \mathrm{mEq}$./litre developed by 24 hours after burning. The findings in Case 7, who developed severe oliguria, are of special interest: the high initial sodium concentration of $150 \mathrm{mEq}$./litre fell steadily to
$30 \mathrm{mEq}$./litre at 24 hours, reached $17 \mathrm{mEq}$./litre at 40 hours, and thereafter remained between 20 and $25 \mathrm{mEq}$./litre until death on the eighth day. This indicates a tubular ability to reabsorb sodium even in the classical severely oliguric form of acute renal failure. Potassium excretion was usually higher than Case 7 indicates; for example, in Case 16 the concentration rose to $191 \mathrm{mEq}$./ litre by 10 hours after burning and remained above $100 \mathrm{mEq}$./litre for 55 hours.

Case 17, who was anuric after 24 hours, may also belong to this group: the urinary sodium level fell from 113 to $56 \mathrm{mEq}$. per litre and the potassium level was high (100-110 mEq. per litre) before the urine flow ceased.

(2) One or two phases of a sodium diuresis lasting up to 24 or 48 hours preceded the fall to a very low sodium value whereas the potassium concentration was generally high. This pattern was found in six patients. In Case 12 (Fig. 7) the sodium concentration mounted to $180 \mathrm{mEq}$./ litre; two episodes of a low concentration (10-20 $\mathrm{mEq}$./litre) occurred, one between 40 and 50 hours after burning and the second between 60 and 96 hours (not shown in the figure). A potassium concentration of $110 \mathrm{mEq}$./litre developed within 12 hours. In Case 14 (Fig. 5) an initial 

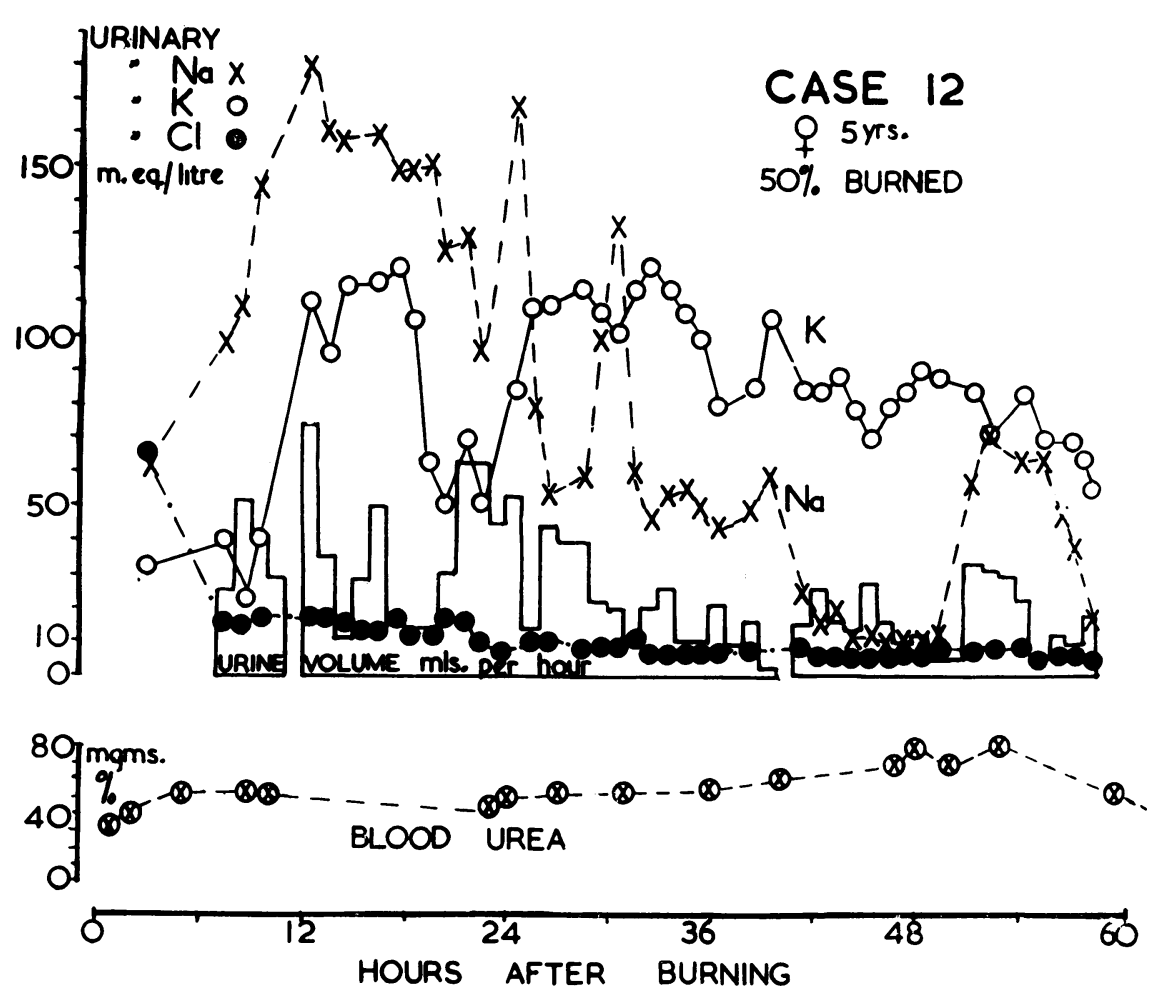

FIG. 7.-Case 12. Note the early onset of a low urinary concentration of chloride, the phase of low sodium excretion, the high urinary level of potassium, and the absence of oliguria (cf. Case 14, Fig. 5). This patient developed only slight temporary azotaemia and survived.

high sodium concentration (100-126 mEq./litre) and high to normal urine flow lasting two hours was followed by a reduced sodium concentration (20 mEq./litre) and urine flow lasting several hours; sodium and water diuresis then returned for 24 to 36 hours, after which oliguria and a low sodium level ( 5 to $10 \mathrm{mEq}$./litre) persisted until death on the fifth day. Potassium excretion increased to $125 \mathrm{mEq}$./litre within two hours of burning as the sodium level fell, and a few hours later fell as the sodium level rose.

(3) In one of the three severely oliguric patients (Case 5) low sodium and high potassium concentrations did not occur. Initially the sodium was $45 \mathrm{mEq}$./litre and then ranged from 50 to 96 $\mathrm{mEq}$./litre and terminally was $77 \mathrm{mEq}$./litre on the fifth day. Potassium concentration slowly fell from 61 to $25 \mathrm{mEq}$./litre during the same period. The low P:U ratios for sodium (1.5 to 3 ) might be interpreted as evidence of impaired tubular activity, b'st the urinary chloride level, which fell steadily from $48 \mathrm{mEq}$./litre on the day of admission to $16 \mathrm{mEq}$./ litre three days later (highest $\mathrm{P}: \mathrm{U}$ ratio $=5.5$ ), suggested continued tubular ability to reabsorb chloride.
Chloride.-The general pattern was a rapid fall to very low values ( 1 to $20 \mathrm{mEq}$./ litre) within 12 hours of burning after which the low chloride excretion continued for days. This occurred in patients with and without severe azotaemia.

In Case 12 (Fig. 7) the chloride fell to 15 $\mathrm{mEq}$./litre by six hours after burning and then was between 4 and $15 \mathrm{mEq}$./litre for four days. The chloride concentration was independent of the sodium and potassium levels; it fell as the sodium and potassium concentrations rose and remained low when the sodium concentration subsequently fell. Chloride excretion was similar in Case 14 (Fig. 5) even though severe azotaemia and proximal tubular necrosis developed and the patients differed in therapy, age, and clinica! course. In the severely oliguric Case 7 the chloride urinary level was maintained between 13 and $33 \mathrm{mEq}$./litre after the first 24 hours (Fig. 6).

Bicarbonate and Organic Acid Excretion.-Our colleague Miss S. Baar showed that when there was a high-sodium, high-potassium, and lowchloride excretion the apparent deficiency in anions (175 to $250 \mathrm{mEq}$. / litre in Cases 12 and 14) 
was largely made up by bicarbonate, and substantial amounts of citric acid, ketoglutaric acid, and hippuric acid were also present.

Tubular Reabsorption of Water and Sodium.The amount of water reabsorbed by the tubules in a given time may be expressed as a percentage of the glomerular filtration rate ( $\frac{\mathrm{UV}}{\mathrm{P}}$ creatinine). If the urine volume $\mathrm{V}$ is expressed as a percentage of this $\left(\mathrm{V} \times \frac{\mathrm{P}}{\mathrm{UV}}\right.$ creatinine $\left.\times 100\right)$, the formula $\overline{\mathrm{P}}$ creatinine $\times 100$ is obtained. This represents the fraction of filtered water excreted as urine. One hundred per cent. minus this value is the amount reabsorbed by the tubules, but for convenience the fraction excreted will be used. Normally this is about $1 \%$ in adults and $2 \%$ in children so that $98 \%-99 \%$ of the filtered water is reabsorbed by the tubules. A definite increase in $\stackrel{\mathbf{P}}{\mathrm{U}}$ creatinine above $2 \%$ indicates a diminished tubular reabsorption of water. This may result from an inhibition of antidiuretic hormone (ADH) activity or from osmotic tubular diuresis or from nervous causes.

The amount of sodium reabsorbed by the tubules may be expressed as a percentage of the amount filtered by the glomeruli in the same period (Platt, 1950). The latter is the plasma sodium level $(\mathrm{PNa}) \times$ the G.F.R. or $\frac{\mathrm{UV}}{\mathrm{P}}$ creatinine. If the amount of sodium in the urine (urine sodium concentration $\times$ volume or $\mathrm{UNa} \times \mathrm{V}$ ) is expressed as a percentage of the amount of sodium filtered by the glomeruli ( $\mathrm{PNa} \times \frac{\mathrm{UV}}{\mathrm{P}}$ creatinine) the percentage of filtered sodium excreted in the urine is $\frac{U}{P} \mathrm{Na} \times \frac{\mathrm{P}}{\mathrm{U}}$ creatinine $\times 100$. One hundred per cent. minus this value is the amount reabsorbed by the tubules, but for convenience the fraction excreted will be used. Normally this varies from about $0.5 \%$ to $1 \%$ so that more than $99 \%$ of filtered sodium is normally reabsorbed. Values lower than $0.5 \%$ indicate an increased tubular rate of reabsorption of sodium, and this is mediated by adrenal hyperactivity, particularly aldosterone secretion and nervous factors.

Platt showed that the percentage of filtered sodium excreted in the urine increased as the plasma creatinine concentration rose, that is, as the glomerular filtration decreased, presumably as a compensatory mechanism so that a "normal" percentage $(0.5 \%$ to $1 \%)$ in these circumstances probably indicates an increased rate of tubular reabsorption of sodium.

The values for water and sodium excretion were available in 12 patients (Cases $4,6,7,9$ to 17) (Figs. 2 and 3). The patterns of excretion of filtered sodium a.nd water behaved independently, although in four patients (Cases 7, 9, 12, and 14) there were early brief phases of parallel increased excretion. Simultaneous values of high percentage excretion of filtered water and low values for sodium occurred and indicated differential tubular activity of a high degree. Such divergent patterns were present in non-azotaemic subjects during the shock period and persisted in all the severely azotaemic patients whether or not tubular necrosis was present.

Water.-Two main patterns (A and B) in the tubular handling of water were found.

A. In five patients (Cases 4, 6, 9, 12, and 15), a!l without persistent azotaemia, there were episodic increases in the fraction of filtered water excreted during the first two or three days (Fig. 2). The peak values varied from $2 \%$ to $15 \%$; each episode lasted four to 12 hours and in four patients normal values were found between the peaks.

B. In the other seven patients, all dying with severe azotaemia, the fraction of filtered water excreted as urine was raised throughout most of the period of study (Figs. 3 and 4). In Cases $7,10,11,13$, and 17 there was a progressive increase in the fraction excreted during the first week after burning or longer, reaching maxima of $5 \%$ to $15 \%$; whilst in Cases 14 and 16 there was a peak excretion of filtered water during the first or second 24 hours (maximum figures $8.3 \%$ and $7.1 \%$ respectively) and a subsequent fall, but the terminal figures were still raised $(5.5 \%$ and $3.1 \%)$.

In general there was a tendency for the percentage of filtered water excreted to increase as the G.F.R. decreased. In those with no or a temporary azotaemia the percentage was greatest during the period of the low G.F.R. The inverse relationship was best marked in the severely azotaemic subjects, not only in patients with a normal or relatively normal urine ouput (e.g., Fig. 3 , Cases 10 and 11), but also in those in whom oliguria was severe (Fig. 3, Cases 7 and 17). The graphs showing percentage excretion of filtered water generally paralleled the rising curves of plasma urea and creatinine. In non-oliguric patients the relatively normal urine flow in the face of a reduced G.F.R. was the result of a decreased tubular absorption. In those who develop severe oliguria the increase in fractional excretion is insufficient to balance the decrease in filtration.

Sodium.-The excretion of filtered sodium during the first 24 hours was in two main patterns (A and B) ; subsequently a normal or lower than normal fraction was excreted in almost every patient. 


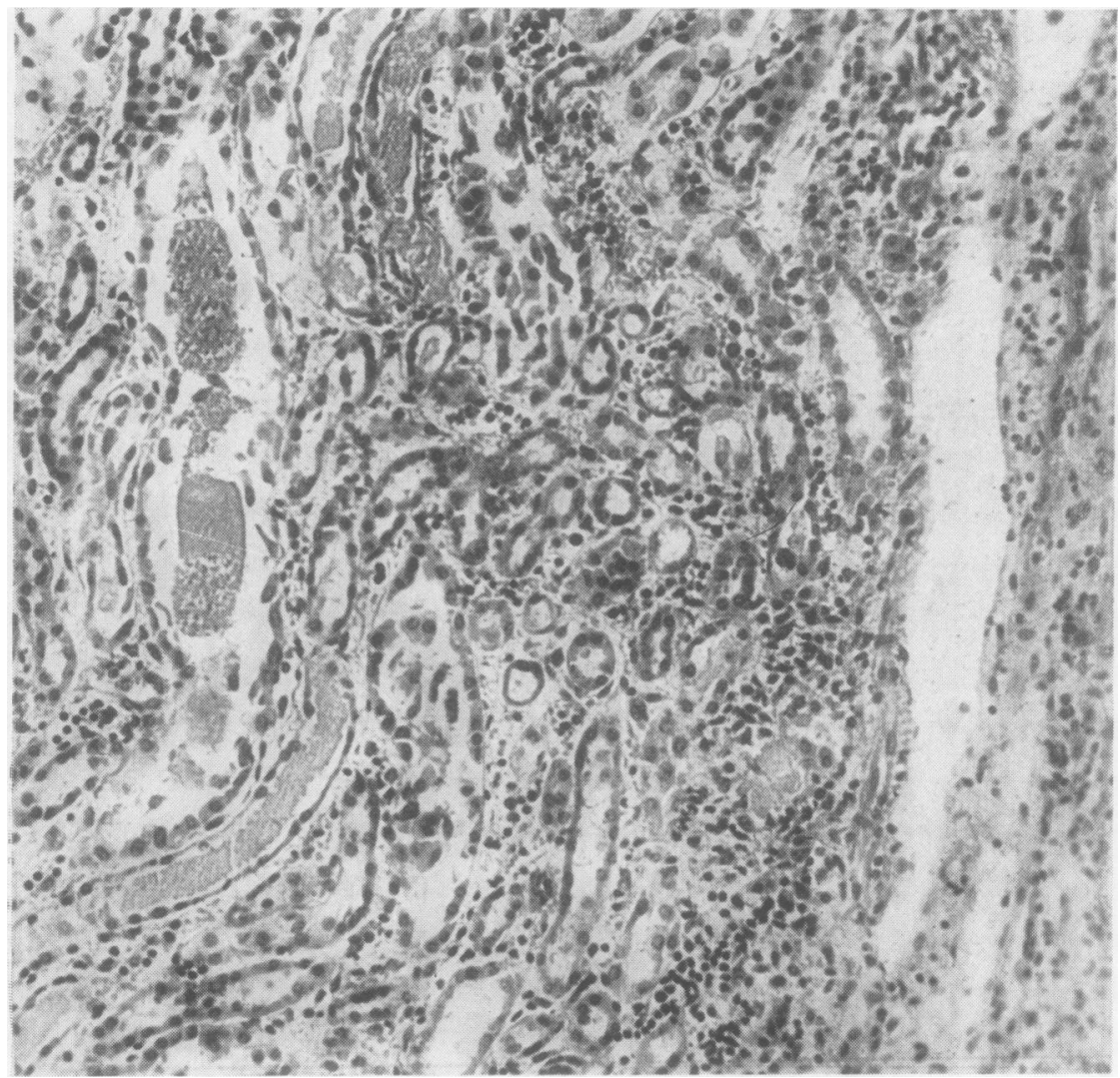

Fig. 8.-Boundary zone of the kidney in Case 10 showing diffuse distal tubular necrosis. On the right many Henle tubules are distended by haemoglobin casts and the tubular epithelium is thinned and necrotic in places. On the left there is a lymphocytic infiltration around the venule partly related to extrudod casts. Haematoxylin and eosin, $\times 210$.

A. In seven patients (Cases 6, 10, 11, 13, 15 to 17) the percentage excretion of filtered sodium was normal or decreased from soon after burning until death or the end of the study (Figs. 2, 3, and 4). The terminal values in the patients with severe azotaemia ranged from $0.06 \%$ to $1.3 \%$ (Case $10=$ $0.6 \%$; Case $11=1.3 \%$; Case $13=0.19 \%$; Case $15=0.06 \%$; Case $16=0.09$; and Case $17=$ $1.8 \%$ at 24 hours after burning) which indicated increased reabsorption of sodium by the tubules.

B. In the other five subjects (Cases 4, 7, 9, 12, and 14) (Figs. 2 and 3 ) the percentage excretion of filtered sodium was increased for one or more periods during the first $\mathbf{2 4}$ hours with peak values rising to between $6 \%$ and $8 \%$; the fraction then decreased to low or normal values. The terminal values in the patients with severe persistent azotaemia were $2.3 \%$ (Case 7 ) and $0.4 \%$ (Case 14 ). Case 14 differed in that a fall preceded and succeeded a relatively prolonged increase in percentage excretion.

The relationship between the pattern of excretion of filtered sodium and the pattern of development of a low urinary sodium level was close but not absolute because the percentage excretion is also dependent on the G.F.R. Five out of seven patients with type A fractional excretion quickly developed a low urinary sodium level, whilst in four out of five of those with type B fractional excretion the low sodium concentration was preceded by a phase of sodium diuresis.

The most significant finding was the increased reabsorption of sodium not only in patients with and without severe azotaemia but also in those with tubular necrosis.

\section{Morphological Changes}

Glomerular and tubular changes are found in the kidneys of many patients who die after burning (Sevitt, 1956a and b ; 1957).

Tubular Necrosis.-This may be divided into (1) distal tubular necrosis (D.T.N.) (Fig. 8) and (2) proximal tubular necrosis (Figs. 9 and 10).

The former is characterized by the precipitation of casts, generally containing much haemoglobin, in the distal and collecting tubules and by tubuloepithelial foci of necrosis or rupture apparently related to pressure or blockage by the casts. An 


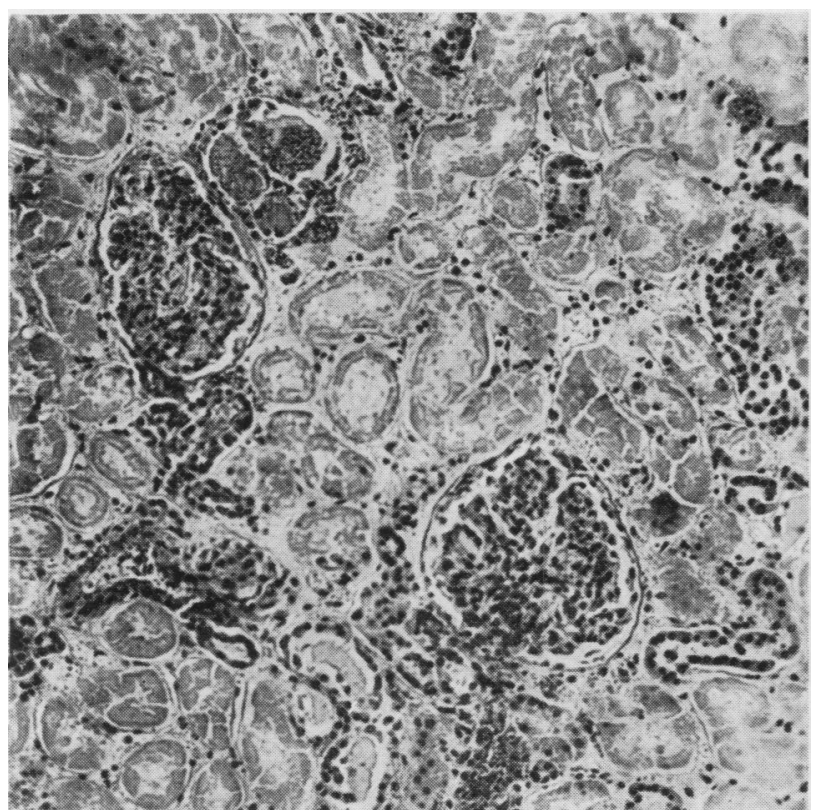

Fig. 9

FIG. 9.-Cortex of kidney in Case 11 showing extensive proximal tubular necrosis. Focal distal tubular necrosis is also present as shown by the distension and blockage of a distal convoluted tubule by a haemoglobin cast (top, left of centre). Haematoxylin and eosin, $\times 160$.

FIG. 10.-Cortex of kidney in Case 14 showing extensive proximal tubular necrosis. Haematoxylin and eosin, $\times 205$.

FIG. 10

inflammatory cellular reaction develops around extruded casts, interstitial oedema occurs, and mural venous thrombi and other evidence of tubulo-venous anastomoses are found. Two varieties are recognized, diffuse distal tubular necrosis when the condition is widespread, and focal distal tubular necrosis when few nephrons are affected.

Proximal tubular necrosis (P.T.N.) is characterized by extensive necrosis of the proximal convoluted tubules, but the distal and collecting tubules in the medulla appear histologically viable.

In the present series 10 of the 11 fatally burned subjects came to necropsy, and the individual results are outlined in Table II. There were three patients without tubular necrosis, two with focal distal tubular necrosis, three with diffuse distal tubular necrosis, and two with extensive proximal tubular necrosis, one of whom also had a focal distal tubular necrosis. In Table IV the patients are divided into four groups according to the development of azotaemia, the reversibility or persistence

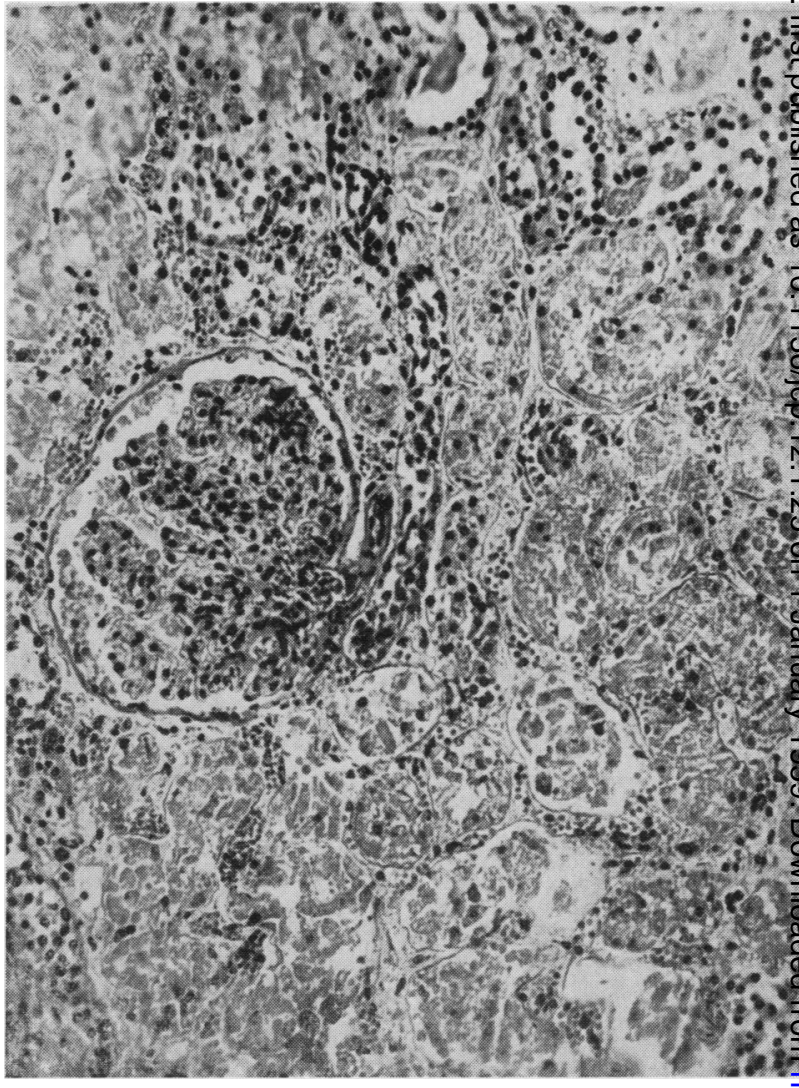

of the fall in the G.F.R., and the presence or absence of significant oliguria. In each group and in at least nine of the 10 patients with kidney histology available the urinary electrolyte pattern indicated continued tubular activity or hyperactivity and discriminating power. Nevertheless, severe azotaemia with or without oliguria was present in the three patients with diffuse distal tubular necrosis (Cases 8, 10, and 17). One of the patients with focal distal tubular necrosis had severe azotaemia and oliguria (Case 5) and the other had had a phase of moderate but temporary azotaemia without oliguria (Case 15). Both of the patients with extensive proximal tubular necrosis (Cases 11 and 14) developed a severe non-oliguric azotaemia. The other three subjects (Cases 1, 13, and 16) showed no evidence of tubular necrosis, but in two of them (Cases 13 and 16) the G.F.R. was low and severe azotaemia developed. They died nine and four days after burning when tubular damage would have been easily detectable had it been present. Neither patient had haemoglobinuria, and this may be significant, since 
TABLE IV

RENAL FUNCTION AND TUBULAR NECROSIS

\begin{tabular}{|c|c|c|c|}
\hline $\begin{array}{l}\text { Azotaemia, G.F.R., } \\
\text { and Urine Flow }\end{array}$ & $\begin{array}{l}\text { Tubular } \\
\text { Activity }\end{array}$ & $\begin{array}{l}\text { No. of } \\
\text { Deaths } \\
\text { per Total } \\
\text { No. of } \\
\text { Patients }\end{array}$ & $\begin{array}{c}\text { Renal Tubular } \\
\text { Necrosis } \\
\text { (No. of Patients) }\end{array}$ \\
\hline $\begin{array}{l}\text { No azotaemia; tem- } \\
\text { porary tall in } \\
\text { G.F.R.; no sig- } \\
\text { nificant oliguria }\end{array}$ & $\begin{array}{l}\text { Low urinary } \mathrm{Na} \\
\text { and } \mathrm{Cl} \text {, high } \\
\mathrm{K}\end{array}$ & 14 & None \\
\hline $\begin{array}{l}\text { Moderate reversible } \\
\text { azotaemia; tem- } \\
\text { porary fall in } \\
\text { G.F.R.; no sig- } \\
\text { nificant oliguria }\end{array}$ & $\begin{array}{l}\text { Low urinary } \mathrm{Na} \\
\text { and } \mathrm{Cl} \text {, high } \\
\mathbf{K}\end{array}$ & 14 & Focal D.T.N. \\
\hline $\begin{array}{c}\text { Severe irreversible } \\
\text { azotaen.ia; fall in } \\
\text { G.F.R. early, sev- } \\
\text { ere and persistent } \\
\text { or early moderate } \\
\text { with subsequent } \\
\text { decline; no sig- } \\
\text { nificant oliguria }\end{array}$ & $\begin{array}{l}\text { Low urinary } \mathrm{Na} \\
\text { and } \mathrm{Cl} \text {, high } \\
\mathrm{K}\end{array}$ & 66 & $\begin{array}{l}\text { Diffuse D.T.N. (2) } \\
\text { Proximal tubular } \\
\text { necrosis }(2) \dagger \\
\text { None (2) }\end{array}$ \\
\hline $\begin{array}{l}\text { Severe irreversible } \\
\text { azotaemia; fall in } \\
\text { G.F.R. early, sev- } \\
\text { ere and persis- } \\
\text { tent; severe oli- } \\
\text { guria or anuria }\end{array}$ & $\begin{array}{l}\text { Low urinary } \mathrm{Na} \\
\text { and } \mathrm{Cl} \text {, high } \\
\mathrm{K}(1 \text { case); } \\
\text { atypical excre- } \\
\text { tion pattern of } \\
\text { electrolytes (1 } \\
\text { case) }\end{array}$ & *33 & $\begin{array}{l}\text { Focal D.T.N. (1) } \\
\text { Diffuse D.T.N. (1) }\end{array}$ \\
\hline
\end{tabular}

* Necropsy refused in one patient. † One also had focal D.T.N Note:(1) The G.F.R. results refer only to 12 patients (see text) (2) In some patients the low urinary sodium was preceded by a phase of sodium diuresis (see text).

D.T.N. = distal tubular necrosis.

a close relationship between this and distal tubular necrosis was previously reported (Sevitt, 1956a and b). It appears that the common association of tubular necrosis with severe azotaemia and a low G.F.R. is due to common pathogenetic factors; the inconstant relationship indicates that one does not cause the other.

Hydropic Tubular Change.-This affected the proximal convoluted tubules in three of the 10 patients. The condition, which was focal in Case 10, quite extensive in Case 17, and particularly well marked in Case 16 (Fig. 11), was not related to tubular necrosis. The affected epithelial cytoplasm was swollen and had a pale, empty appearance not due to lipoid or glycogen. Close examination showed a sparse fine eosinophilic structure in the cytoplasm as if various cellular structures were separated by an excess of fluid. The nuclei were generally basally situated and the cell borders thickened as if compressed by fluid.

\section{Relationship to Lactosuria}

Hydropic tubular swelling does not appear to be a degenerative phenomenon. It can be produced by the administration of sucrose, lactose, and other saccharides, and is probably an osmotic effect related to a disturbance in the normal osmotic relationship between the filtrate and tubular epithelium (Lamy, Mayer, and Rathery, 1906 ; Helmholz, 1933 ; Wilmer, 1944). Lactosuria, which may follow the application of penicillinlactose powder to burns, was found in three of the eight patients studied (Cases 10,11, and 16), in two of whom hydropic change was present. Lactosuria was not tested for in the other patient with hydropic tubules (Case 17).

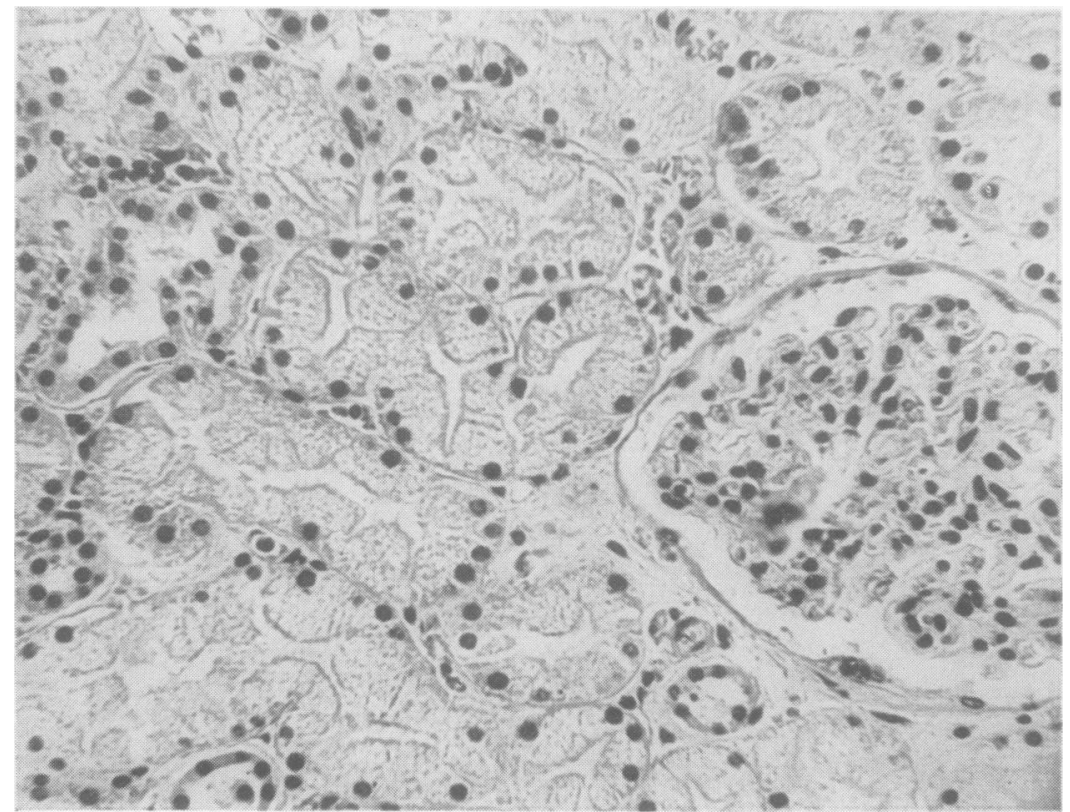

FIG. 11.-Cortex of kidney in Case 16 showing hydropic change in the proximal convoluted tubules. Haematoxylin and eosin, $\times 270$. 
FIG. 12.-Cortex of kidney in Case 8 showing multiple hyaline (P.A.S.-positive) droplets or granules in the epithelial cytoplasm of the neck of 'a proximal convoluted tubule. Periodicacid-Schiff and haematoxylin, 360.

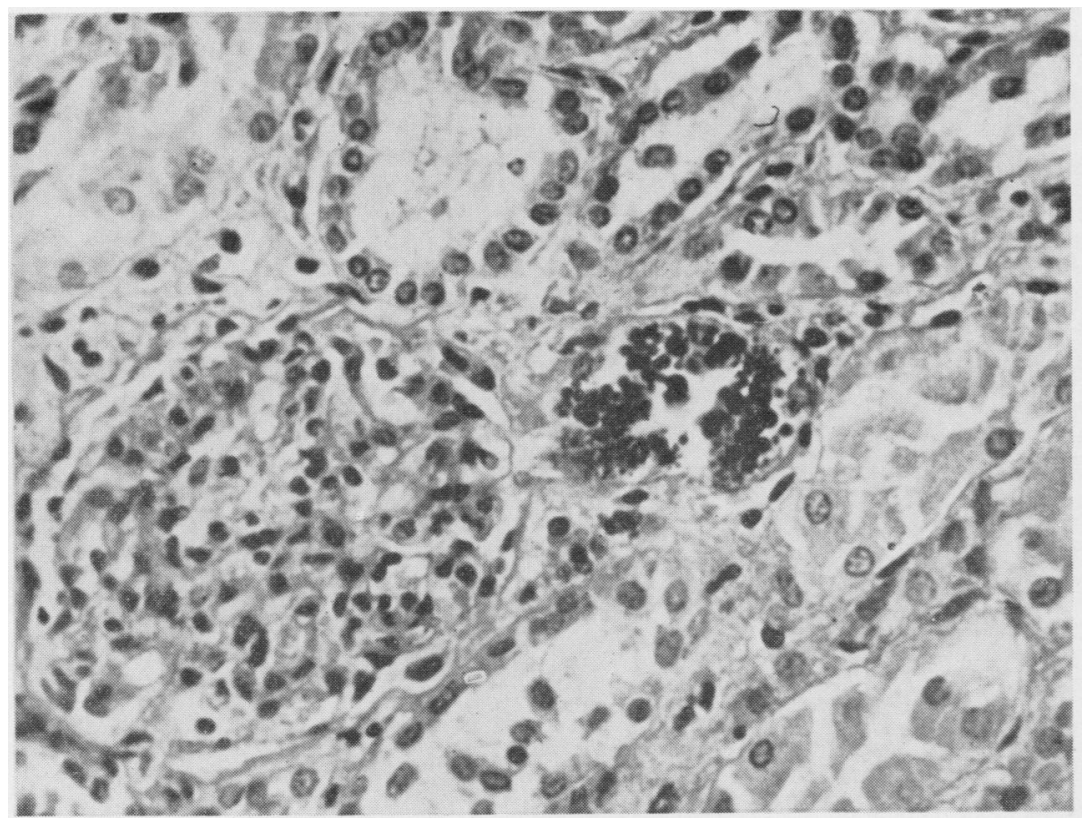

A possible relationship to a decreased tubular absorption of water was considered but was impossible to evaluate because the condition is known to be reversible. Its appearance was not necessarily related to the presence or absence of oliguria.
Hyaline Droplet Change.-This affected the neck-like origin of some or many proximal convoluted tubules of three subjects (Cases 8, 13, and 16) (Table II). The cytoplasm contained multiple fine or coarse eosinophilic hyaline droplets or granules (Fig. 12) ; these were periodic-acid-Schiff

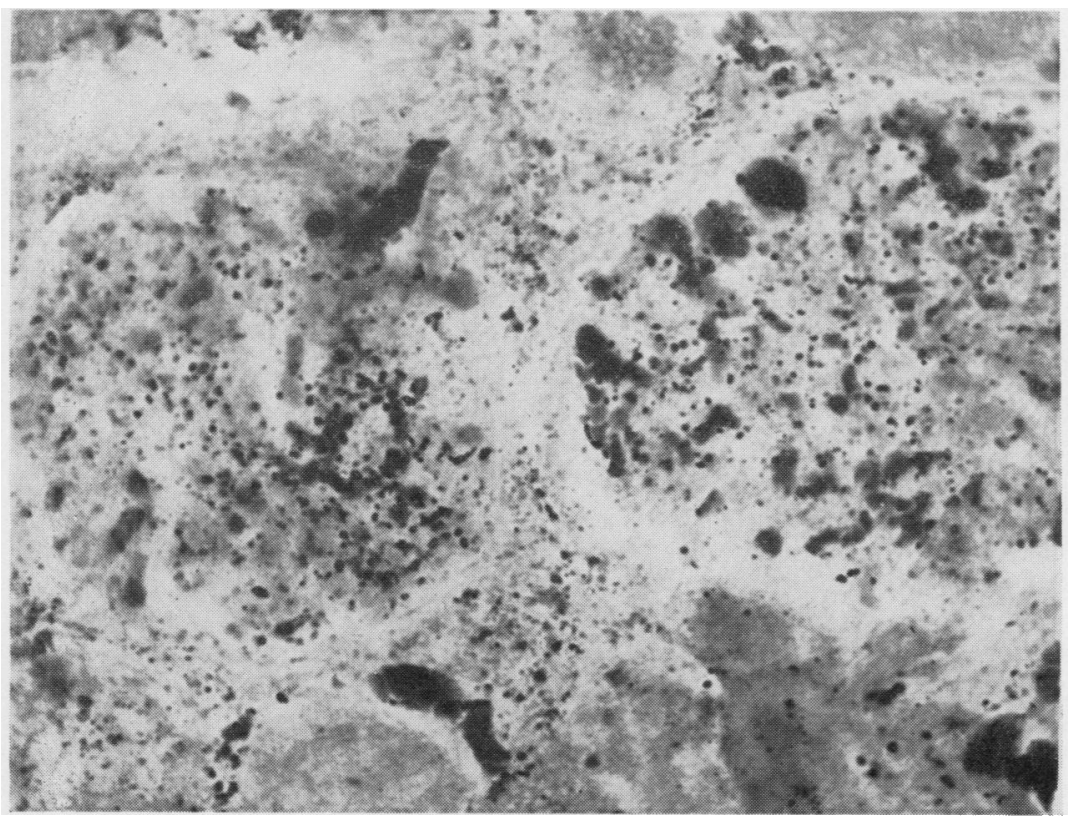

FIG. 13.-Two glomeruli in Case 17 These contain numerous fine droplets of fat (black dots) which are outside the capillary lumina and within epithelial and possibly endothelial cells. Frozen section of kidney stained by oil-red-O for lipid, $\times \mathbf{3 5 0}$. 
positive and probably protein in nature containing a muco- or glycoprotein. Their presence was not necessarily related to tubular necrosis. Similar droplets may be found in many conditions, including nephritis, nephrosis, eclampsia, and gastro-enteritis in children, but their origin is debatable. They might be tubulo-degenerative in origin (Allen, 1951), related to the reabsorption of filtered protein (Smetana, 1947 ; Oliver, Straus, Kretchmer, Dickerman, and Cherot, 1955), or possibly to reabsorption of glomerular glycoprotein released by adrenocortical hyperactivity (Masson, del Greco, Corcoran, and Page, 1953). A relationship to plasma transfusion cannot be close because it was absent in most of the present patients.

Lipid Glomerular Droplets. - Multiple fine droplets of fat are often seen in the glomerular tufts of burned patients when appropriately stained frozen sections are examined (Fig. 13). The droplets, which are generally 1-3 $\mu$ in diameter, appear as a fine dusting within the epithelial cells, some of which are closely packed with numerous globules. They are possibly also within endothelium but are rarely found within capillary lumina. Their density may vary from a heavy dusting $(+++)$ to moderate numbers $(++)$ or a few scattered droplets $(+)$.

In the present series a +++ or ++ degree of change was found in five subjects (Cases 11, 13, 14,16 , and 17) all of whom had severe azotaemia ; few $(+)$ or no droplets were found in the other five (Cases 1, 5, 8, 10, and 15), three of whom had severe azotaemia, one a reversible azotaemia, and one no azotaemia (Table II). The condition is not directly related to tubular necrosis because it was present in two patients without this condition (Cases 13 and 16) and was heavy, moderate, or slight in subjects with proximal or diffuse distal tubular necrosis.

\section{DISCUSSION}

\section{Tubular Function and Tubular Necrosis}

The results summarized and correlated in Tables II and IV show that persistent tubular activity was found whether or not the patient developed azotaemia, whether or not the azotaemia and the fall in the G.F.R. were temporary or persistent, whether or not oliguria occurred, and irrespective of the character and extent of tubular necrosis. The latter was often found in azotaemic patients but not invariably: two patients without tubular necrosis became severely azotaemic and another with only a focal distal tubular necrosis developed severe oliguria. The converse, diffuse distal tubular necrosis without azotaemia, has been previously reported (Sevitt, 1956a). The previous finding of diffuse distal tubular necrosis in severely oliguric and non-oliguric subjects has been confirmed; and it is now found that extensive proximal tubular necrosis may occur without oliguria. The results mean that tubular necrosis cannot be the pathological basis of acute renal dysfunction after burning. Both are often present because they have common pathogenetic factors. This view is contrary to the general belief that the tubular lesion or lesions termed by different workers "lower nephron nephrosis," " pigment nephrosis," " acute tubular necrosis," " tubulorhexis," and " nephrotoxic lesions" impose a characteristic pattern of renal failure (Lucké, 1946; Bull, Joekes, and Lowe, 1950 ; Bull and Dible, 1953 ; Oliver, MacDowell, and Tracy, 1951 ; Oliver, 1953). Bull et al. (1950) described a period of anuria or severe oliguria followed by early and late diuresis. The urine in the oliguric and early diuretic phases was said to approximate to a plasma filtrate; the $P: U$ ratios for sodium and chloride were low and the clearance values for creatinine, para-aminohippuric acid, and other substances were greatly reduced. They attributed these findings to unselective back diffusion and explained dysfunction in terms of morphology, correlating oliguria with tubular necrosis and early diuresis with regenerating tubular cells. Correlation, however, does not prove a causal relationship. Their cases and those of other workers were selected because of severe oliguria, but in our experience with burned patients oliguria is less common than the non-oliguric form of acute azotaemia and is merely part of the spectrum of renal dysfunction. The interpretation of some of the reported findings is not above criticism. For example, the hyperexcretion of potassium in the so-called early diuretic phase is surely a manifestation of intense tubular activity.

Our results indicate that many nephrons continue to function even when tubular necrosis is histologically extensive. The damaged nephrons are excluded from the urine flow, but the remainder continue to function and determine the composition of the urine. This concept centres the renal problem not on tubule dysfunction but upon glomerular filtration and on the size and reserves of the functioning tubular mass.

The pattern of electrolyte excretion is independent of tubular necrosis. It is related to the hormonal response of the body to trauma, the deviation of sodium and chloride into the burn oedema, and their modifications by fluid therapy. There is ample evidence of prolonged adreno- 
cortical hyperactivity in severely burned patients (Harkins and Long, 1945; Sevitt, 1951, 1954, 1955 ; Evans and Butterfield, 1951 ; Symington, Currie, Curran, and Davidson, 1955), mainly related to glucocorticoid secretion (Tompsett and Oastler, 1947 ; Hume, Nelson, and Miller, 1956). Although aldosterone output in burns has not been reported the low urinary $\mathrm{Na} / \mathrm{K}$ ratios (Llaurado, 1955) in our patients suggest that there is an increased secretion of this hormone. The water and electrolyte disturbance and hormonal responses in burned patients differ qualitatively and quantitatively from the changes in unburned patients ; this may partly explain the differences in our results from those of other workers, most of whose patients developed severe oliguria after traumatic shock, abortion, haemolytic transfusion reactions, and other conditions unrelated to burning.

The aetiology of tubular necrosis after burning has been discussed elsewhere (Sevitt, 1956b, 1957). Both the fall in G.F.R. and tubular necrosis have common pathogenetic factors. Renal vasoconstrictive ischaemia and the precipitation of haemoglobin casts from oligaemia and haemoglobinaemia may be followed by distal tubular necrosis, whilst renal vasoconstrictive ischaemia and a redistribution of the intrarenal blood flow (aided by advancing age and pre-existing nephrosclerosis) may be followed by proximal tubular necrosis.

\section{Oliguria and Hyperpotassaemia.-Hyperpotas-} saemia regularly develops in patients with acute oliguria and is said to be related to the renal inability to excrete potassium because of tubular necrosis. Our findings indicate that oliguria is the important factor and not tubular necrosis; a significant hyperpotassaemia was found only in the three severely oliguric patients (Cases 5, 7, and 17) who showed either a rapid or progressive rise to $6.1,7.3$, and $6.9 \mathrm{mEq}$. of potassium per litre of plasma respectively. The non-oliguric subjects, including those with proximal or diffuse distal tubular necrosis, had normal plasma potassium levels (3.6-5.0 mEq./litre); three of them had phases of hypopotassaemia lasting one to three days.

Oliguric and Non-oliguric Azotaemia.-Correlation of the G.F.R. with the rate of excretion of urine has shown that the proportion of filtered water passed as urine is often much increased; overall it is inversely related to the G.F.R., particularly in those with a persistent fall in filtration and a severe azotaemia. The reduced tubular reabsorption of water was found in those with severe oliguria as well as in those who passed normal or polyuric volumes. It is evident that the relatively normal or increased urine volume in the face of a reduced G.F.R. is dependent on a sufficiently reduced tubular reabsorption of water ; oliguria occurs when the decrease in tubular reabsorption is insufficient to balance the decrease in filtration.

The reduced reabsorption might be interpreted as an impaired tubular function, but it would then be a selective impairment because other absorptive and excretory powers seem hyperactive. It may be compensatory to the low G.F.R., since the direct relationship between the percentage of filtered water excreted and the plasma creatinine (or urea) is analogous to the compensatory sodium-excretion mechanism described by Platt (1950) in chronic renal failure.

The decreased reabsorption of water might be mediated by a decreased secretion of pituitary anti-diuretic hormone and/or an increased secretion of adrenal 17-hydroxycorticosteroids. Baar (1956) found that the peptide fraction isolated from the pooled urines of burned patients with reduced urine flows had little anti-diuretic activity. However, it is not known whether the decreased excretion of anti-diuretic hormone occurs only in those with a reduced tubular reabsorption of water. Anti-diuretic hormone secretion is known to be inhibited after expansion of the extracellular space by intravenous normal saline (Strauss, Davis, Rosenbaum, and Rossmeisl, 1951) and might be mediated by the oedematous burn which is greatly expanded by fluid therapy. The increased plasma level of 17-hydroxycorticosteroids found by Hume et al. (1956) could contribute to the decrease in tubular reabsorption of water since an antagonism between the action of anti-diuretic hormone and hydrocortisone is known (Graber and Beaconsfield, 1955; Raisz, McNeely, Saxon, and Rosenbaum, 1958). A possible contributory cause is osmotic diuresis from lactosuria aided by the temporary glycosuria which is a feature of extensively burned patients.

\section{Fall in Glomerular Filtration}

The G.F.R. invariably fell considerably during the first 12 hours after burning even though transfusion therapy was most intense during this time. In some patients, mainly children, the fall was temporary and normal filtration was re-established by 24 to 72 hours; in others, mainly adults, the low rate of filtration persisted or even further decreased until death supervened. The influence of age on renal function is similar to that found previously when azotaemia was used as the index of glomerular function (Sevitt, 1956a). The 
different response of children to that of adults may represent a renal haemodynamic resiliency which is deficient in the higher age group. These patterns of change in the G.F.R. are similar to those described by Dziemian (1948) in both treated and untreated burned goats, but they are in conflict with the results of Haynes, DeBakey, and Denman (1951), who reported normal or higher than normal rates of filtration in severely burned patients. Their studies are confined to patients with high urine flows $(120 \mathrm{ml}$. per hour or more) and their clearance results were based on only two 20-minute urine collection periods. The rapid fluctuations found by us indicate the danger of drawing conclusions from one or two estimations, and also indicate that the normal mechanism stabilizing glomerular filtration has been impaired even in those without azotaemia.

Pathogenesis.-The main problems are (1) the cause and mechanism of the initial fall of the G.F.R. after burning, and (2) the changes which can prevent a return to normal filtration in patients receiving early and energetic transfusion.

(1) The Initial Fall in G.F.R.-The available evidence indicates that the major mechanism is a severe renal vasoconstriction which reduces the glomerular blood flow and so influences filtration. Normally the kidneys received $20-25 \%$ of the cardiac output, but Lauson, Bradley, and Cournand (1944) reported that in patients with traumatic shock (also one burned patient in shock) the fraction is greatly reduced. A severe reduction in cardiac output is accompanied by a proportionately greater fall in the renal blood flow often to $10 \%$ of the normal. This must be due to a selective renal vasoconstriction. Studies in animals and in man have shown that extensive burns are also followed by a major fall in cardiac output at least partly related to the development of oligaemia (Richards, 1943-44 ; Hardy, Neely, Wilson, Lovelace, and Jabbour, 1955; Dobson and Warner, 1955; Gilmore and Handford, 1956). At first the blood pressure remains normal or even rises, indicating a marked increase in peripheral resistance.

Renal vasoconstriction may also be produced by humoral agents, among which are noradrenaline, which is known to be excreted after burning (Goodall, Stone, and Haynes, 1957), the vasoconstrictive substance in plasma described by Page (1943), and substances released from lysed red cells and platelets, possibly including 5hydroxytryptamine.

Glomerular filtration may also be retarded by a phase of therapy-induced hyperproteinaemia $(8$ to $9.5 \mathrm{~g}$. per $100 \mathrm{ml}$.) in some patients transfused with plasma containing about 5 g. protein per 100 $\mathrm{ml}$. (Graber, unpublished, quoted by Sevitt, 1957).

(2) Irreversible Fall in G.F.R.-A return to normal or near-normal kidney function after early and energetic fluid therapy occurred in only eight out of the 17 patients, whilst in the others the low G.F.R. was unaffected. This ability to respond to therapy seems related to the age of the patient and the extent of burning. None of the four patients, adults or children, with burns involving less than $30 \%$ of the body surface developed an irreversible renal failure, but the latter occurred in all the seven more extensively burned adults and in two of the six more extensively burned children.

We do not know the cause of the persistent fall in filtration, but the following facts and speculations are worthy of consideration.

Although Hardy and his colleagues (1955) found that intravenous therapy in burned patients was followed by a prompt improvement or restoration of the cardiac output, this was not the experience of Gilmore (1957) in burned dogs. He found that restoration of plasma volume did not always produce a normal cardiac output, nor did a normal cardiac output necessarily indicate restoration of plasma volume. In addition restoration of cardiac output may not be followed by a normal distribution of blood flow which could be deviated from the kidneys into the acutely inflamed burned area and into the congested gastro-intestinal tract and spleen.

It is also possible that the reduced renal flow might promote the renal secretion of " renin" or an allied substance which could then perpetuate the vasoconstriction.

Tubular necrosis must reduce the functioning nephron mass and contribute to the reduction in the G.F.R. Oliver et al. (1951) pointed out that necrosis, rupture, or blockage by a cast, even when localized to part of a tubule, would interfere with the functioning of the whole nephron. The development of interstitial oedema in kidneys with tubular necrosis has suggested that there is a rise in intrarenal pressure which might reduce intrarenal blood flow after filtration and produce oliguria. However, de Wardener (1955) failed to demonstrate a rise in intrarenal tension in the kidneys of dogs with necrosis produced by ligation of the renal artery, and Munck (1958) also failed to demonstrate a rise in tension in five patients with oliguric failure after wedging the tip of a catheter within a renal vein. 
Glomerular Changes. - Tubular necrosis cannot be the whole explanation, because it was not found in two patients with an irreversible fall in filtration. Moreover, Munck (1958) recently found that the degree of fall in the creatinine clearance is far greater than can be accounted for by the reduction in renal blood flow. In six patients with oliguric failure the average renal blood flow (measured after inhalation of radioactive keypton and renal vein catheterization) was reduced to about one-third of normal whilst creatinine (G.F.R.) was reduced to $1 \%$ or less. This suggests to us that changes within the glomeruli may play a part in the production and maintenance of a low filtration rate.

It is the common belief that there is no histological abnormality of the glomerulus which can explain acute renal failure, but our finding of large numbers of fine fatty droplets in the glomerular epithelium and possibly in the endothelium of the tuft makes reconsideration of this necessary. Electronmicroscopic studies of the normal glomerulus (Pease, 1955) show that the capillary endothelium is full of fine pores and that the epithelium has multiple fenestrations between fine foot-like projections cemented to the basement membrane. This indicates that the only glomerular structure capable of acting as a filter is the basement membrane. It is worth speculating whether subtle glomerular changes, difficult to define in ordinary histological sections, such as acute swelling of the epithelial or endothelial cytoplasm, may be present in patients with a persistent fall in the G.F.R. Such changes would reduce the porosity of the cells apposed to the filtering membrane. In this connexion the appearance of fatty droplets in the epithelium may be a histological sign of a more serious and subtle change affecting filtration. Changes in the glomerular basement membrane itself are also worthy of study.

\section{SUMMARY AND CONCLUSIONS}

Renal function was studied in 17 extensively burned patients admitted and treated by intravenous therapy by one to three and a half hours after burning and was related to the renal histological changes in those who subsequently died. Patterns of glomerular and tubular function were established from the examination of serial specimens of urine, hourly at first, and of appropriate blood samples; from these estimates were made of the glomerular filtration rate (creatinine clearance), urea clearance, plasma creatinine and urea levels, and of the excretion of water, sodium, potassium, and chloride.

Evidence is presented that non-selective back diffusion plays no part in the composition of the urine in patients with acute renal failure and that therefore the G.F.R. could be measured by creatinine clearance.

The G.F.R. fell considerably during the first few hours after burning even though transfusion with plasma was most intense at this time. In some patients, mainly children, recovery occurred by 24 to 72 hours and azotaemia was absent or moderate and temporary. In others, mainly adults, the low G.F.R. persisted or even worsened until death supervened; in them azotaemia was considerable, severe oliguria sometimes developed, but more often the urine flow was normal, nearnormal, or even polyuric.

A diminished tubular reabsorption of water was found in oliguric and non-oliguric patients with severe azotaemia; when this balanced the low rate of filtration the urine flow was normal whilst oliguria occurred when the fall in the G.F.R. was greater.

Similar patterns of tubular activity (including the maximal power to reabsorb sodium and chloride and to excrete high levels of potassium and a tubular ability to differentially handle urea, creatinine, water and electrolytes) were found in patients whether or not they developed azotaemia, a persistently low G.F.R., or oliguria.

Similar tubular activity was found in those who survived and in those who died with proximal or distal tubular necrosis or without tubular necrosis.

The results conflict with the concept that acute renal failure is characterized by loss of tubular function, that it is due to renal tubular necrosis, and that severe oliguria or anuria is always present. The major dysfuncion is glomerular and not tubular, even though tubular necrosis and blockage by casts are often found. The aetiological factors relating to glomerular and tubular function are discussed. Attention is drawn to a possible structural change in the glomeruli as the cause of the persistent fall in the G.F.R. and is focused on the functioning nephron mass and reserves to explain the composition of the urine.

One of us (S.S.) is a part-time member of the Medical Research Council and the other (I. G. G.) is research registrar to $\mathrm{Mr}$. R. Clarke. We gratefully acknowledge the co-operation of our clinical colleagues, by whom the patients were treated, and the nursing staff in the Burns Unit. We are indebted to Miss S. Baar and Messrs. J. Skelding and J. Adams for numbers of biochemical investigations, to $\mathbf{A}$. Randle for the histological preparations, to $\mathrm{Mr}$. $\mathrm{R}$. 
Gill for help with the photomicrography, and to Mrs. M. Swinden for the secretarial work.

\section{REFERENCES}

Allen, A. C. (1951). The Kidney, p. 207. Grune and Stratton, New York.

Baar, S. (1956). J. clin. Path., 9, 144.

Brod, J., and Sirota, J. H. (1948). J. clin. Invest., 27, 645.

Bull, G. M., and Dible, J. H. (1953). In Recent Advances in Pathology, 6 th ed., p. 284 (ed. by G. Hadfield). Churchill, London.

- Joekes, A. M., and Lowe, K. G. (1950). Clin. Sci., 9, 379

Didenko, I. A. (1956). Khirurgiya, No. 5, p. 12.

Dobson, E. L., and Warner, G. F. (1955). Fed. Proc., 14, 39.

Dziemian, A. J. (1948). Ibid., 7, 29.

Evans, E. I., and Butterfield, W. J. H. (1951). Ann. Surg., 134, 588.

Fearon, W. R. (1946). An Introduction to Biochemistry, 3rd ed. p. 123. Heinemann, London.

Gilmore, J. P. (1957). Amer. J. Physiol., 190, 513.

- and Handford, S. W. (1956). J. appl. Physiol., 8, 393.

Goodall, McC., Stone, C., and Haynes, B. W. (1957). Ann. Surg., $145,479$.

Graber, I. G. (1955). Unpublished data.

— and Beaconsfield, P. (1955). Brit. med. J., 2, 704.

- and Hancock, J. (1955). Unpublished.

Hardy, J. D., Neely, W. A., Wilson, F. C., Lovelace, J. R., and Jabbour, E. (1955). Surg. Gynec. Obstet., $101,94$.

Harkins, H. N., and Long, C. N. H. (1945). Amer. J. Physiol., 144, 661.

Haynes, B. W., DeBakey, M. E., and Denman, F. R. (1951). Ann. Surg., 134, 617.

Helmholz, H. F. (1933). J. Pediat., 3, 144.

Hume, D. M., Nelson, D. H., and Miller, D. W. (1956). U.S. nav. med. Res. Inst., Medical Project Report, 14, 87; and in Ann. Surg., 143, 316 (1956).

Lamy, H., Mayer, A., and Rathery, F. (1906). J. Physiol. Path. gen., $8,624$.

Lauson, H. D., Bradley, S. E., and Cournand, A. (1944). J. clin. Invest., 23, 381.
Llaurado, J. G. (1955). Proc. Univ. Otago. med. Sch., 33, 19.

Lucké, B. (1946). Milit. Surg., 99, 371.

Masson, G. M. C., Greco, F. del, Corcoran, A. C., and Page, I. H. (1953). A.M.A. Arch. Path., 56, 23.

Munck, O. (1958). Renal Circulation in Acute Renal Failure. Blackwell, Oxford.

Oliver, J. (1953). Amer. J. Med., 15, 535.

- -, MacDowell, M., and Tracy, A. (1951). J, clin. Invest., $30,1305$.

, Straus, W., Kretchmer, N., Loe, Y. C., Dickerman, H. W., and Cherot, F. (1955). J. Histochem. Cytochem., 3, 277.

Page, I. H. (1943). Amer. J. Physiol., 139, 386.

Pease, D. C. (1955). J. Histochem. Cytochem., 3, 295.

Philips, R. A., and Hamilton, P. B. (1948). Amer. J. Physiol. 152, 523.

Platt, R. (1950). Clin. Sci., 9, 367.

Raisz, L. G., McNeely, W. F., Saxon, L., and Rosenbaum, J. D. (1957). J. clin. Invest., 36, 767.

Richards, D. W. (1943-44). Harvey Lect., 39, p. 217.

Rolf, D., Surtshin, A., and White, H. L. (1949). Proc. Soc. exp. Biol. (N.Y.), 72, 351.

Schales, O., and Schales, S. S. (1941). J. biol. Chem., 140, 879.

Sevitt, S. (1951). Brit. med. J., 1, 976.

- (1954). Ibid., 1, 154.

- (1955). J. Path. Bact., 70, 65.

_- (1956a). J. clin. Path., 9, 12.

- - (1956b). Ibid., 9, 279.

- (1957). Burns: Pathology and Therapeutic Applications. Butterworths, London.

Smetana, H. (1947). Amer. J. Path., 23, 255.

Strauss, M. B., Davis, R. K., Rosenbaum, J. D., and Rossmeisl, E. C. (1951). J. clin. Invest., 30, 862.

Symington, T., Currie, A. R., Curran, R. C., and Davidson, J. N (1955). In Ciba Foundation Colloquia on Endocrinology, vol. 8, p. 70. London.

Tompsett, S. L., and Oastler, E. G. (1947). Glasg. med. J., $28,349$.

Topley, E., and Jackson, D. MacG. (1957). J. clin. Path., 10, 1.

Wardener, H. E. de (1955). Lancet, 1, 580.

Wilmer, H. A. (1944). Amer. J. Physiol., 141, 431. 